Article

\title{
A Fuzzy Logic-Based Tool for the Assessment of Corporate Sustainability: A Case Study in the Food Machinery Industry
}

\author{
Eleonora Bottani *, Maria Carmen Gentilotti and Marta Rinaldi \\ Department of Engineering and Architecture, University of Parma, viale delle Scienze 181/A, 43124 Parma, \\ Italy; mariacarmen.gentilotti@studenti.unipr.it (M.C.G.); marta.rinaldi@unipr.it (M.R.) \\ * Correspondence: eleonora.bottani@unipr.it; Tel.: +39-0521-905872
}

Academic Editor: Fabio Carlucci

Received: 20 February 2017; Accepted: 5 April 2017; Published: 11 April 2017

\begin{abstract}
This paper develops a quantitative tool for the assessment of sustainability at the company's level, taking into account its three key perspectives, i.e., economic, environmental and social. The proposed framework is grounded on fuzzy logic and in particular on a monotonic hierarchical fuzzy inference tool, as an effective means to gather the judgements and scores against the key performance indicators (KPIs) of each sustainability perspective into an aggregated index. In developing the fuzzy inference tool, we also solve some typical issues related to the assessment of sustainability, e.g., the identification of benchmark values to rate the company's performance against each sustainability KPI. The architecture of the fuzzy inference tool was embodied in an ad hoc software developed in Microsoft Excel ${ }^{\mathrm{TM}}$ (Microsoft Corporation, Albuquerque, NM, USA), which makes it easy to use the proposed framework in practical situations. The potential of the software tool developed is illustrated by means of a case study, targeting a food machinery company, for which the overall evaluation of sustainability is carried out.
\end{abstract}

Keywords: sustainability evaluation; fuzzy inference; software tool; food machinery industry; case study

\section{Introduction}

Over the past few decades, the concepts of sustainability and sustainable development have emerged as humanity has become more cognizant of its increasing impact on the world [1]. Sustainable development, i.e., "the development that meets the needs of the present without compromising the ability of future generations to meet their own needs" [2], is more and more relevant to industry and supply chains. It is nowadays acknowledged that sustainable development should embrace three main perspectives, i.e., economic, environmental and social sustainability [3-6]. Seuring and Müller [7] introduced the concept of sustainable supply chain management (SSCM) to describe the situation where a company should embrace the three sustainability perspectives, as the same time maintaining its competitiveness. SSCM describes "the management of material, information and capital flows as well as cooperation among companies along the supply chain while taking goals from all three dimensions of sustainable development, i.e., economic, environmental and social, into account which are derived from customer and stakeholder requirements" [7].

Recently, several authors pointed out the importance of measuring the company's performance in terms of sustainability [8]. The purpose of sustainability assessment is to provide the decision-makers (DMs) with an evaluation of a system's global (or local) perspectives, to assist them to determine which actions to undertake in an attempt to make the system more sustainable [9]. Searcy [10] highlighted that sustainability performance measurement requires a systematic, structured and integrated approach 
that considers all aspects of the enterprise sustainability. However, there are some main challenges related to this point. First, before an assessment can be made, all of the key aspects of sustainability should be identified, which is not trivial [11]. Second, even if all of the relevant aspects have been considered in the evaluation, measuring all of them in a meaningful unit is not always feasible [12]. This is in particular the case for the social sustainability perspective, which still lacks specific and quantitative indexes [5]. When more metrics are available for a similar performance, a further issue is that different companies might decide (even arbitrarily) to use different indexes [13]. Indeed, the relevance of each index could depend on the specific company evaluated or on the market segment where this company operates. Third, to derive an overall evaluation of the system's sustainability, the scores obtained against each indicator need to be aggregated into a composite score. As a matter of fact, although the combination of more metrics in a composite index involves losses of information, composite indicators are increasingly adopted in the context of sustainable development, as they allow for the simultaneous evaluation of multiple aspects, which can then be summarized into a single comparable index [12]. However, several issues can complicate the aggregation. First, different measurement units are typically used when evaluating different indicators, which makes it difficult to aggregate them. Furthermore, some indicators may have a qualitative/subjective nature, while other ones can be measured in quantitative terms [12]. Finally, to be meaningful, indicators often need to be compared to a reference value, such as a threshold or benchmark, because of the need for assessing how a company is distant from a target [14-16]. Indeed, the absolute numerical value of a key performance indicator (KPI) can obviously change depending on the company examined or the industry field, and therefore, it tells very little about the sustainability level of a company [17]. This is, for instance, the case for the company's turnover: a turnover of, e.g., 1,000,000 $€ /$ year can be judged as high in a specific market and low in a different one, with a different impact on the economic sustainability.

Taking into account the considerations above, this paper attempts to provide an integrated and quantitative tool for the assessment of the company's sustainability. The proposed framework aims at considering all three perspectives of sustainability, i.e., the economic, social and environmental ones, and integrating the scores against the different indicators in an overall evaluation index. A monotonic hierarchical fuzzy inference tool is used as the aggregation method, in line with the fact that fuzzy logic is recognized as an effective tool to evaluate ill-defined concepts, such as sustainability [18-20].

The paper proceeds as follows. The next section reviews the literature relevant to this study. Section 3 details the fuzzy inference tool developed, together with its implementation into an ad hoc software tool. Section 4 provides an application example, where the proposed tool is used to evaluate the sustainability of a food plant manufacturing company. Section 5 concludes by summarizing the key findings of the study, the main implications and limitations and highlighting future research directions.

\section{Literature Review}

It is a common practice of the DMs to address the economic pillar of sustainability [7]. From an economic perspective, a supply chain should aim at providing products or services to the final customer at the minimum cost. Nonetheless, increasing efforts have recently been directed at the environmental pillar of sustainability, i.e., the adoption of environmentally-conscious business practices, with the aim to avoid the over-use of depleting resources or, as an alternative, to privilege the use of resources that have less potential for depletion [21]. Researchers have examined different, stand-alone topics related to the environmental pillar of sustainability [22-30], including also reviews on the topic [7,31-33]. Compared to the environmental and economic perspectives, the pillar associated with social sustainability is less analyzed and still not well defined [1]. Typically, researchers relate the social perspective to legislative issues, human health or safety problems, as well as cultural or ethical decisions (e.g., gender equity and fair distribution of job opportunities) [34,35]. Researchers have also investigated specific topics in the field of sustainability, e.g., the relationships between reverse logistics and social sustainability [36] or sustainable supplier selection problems [37-39]. 
The available literature offers several models that try to evaluate simultaneously the three main pillars of sustainability. However, it is appropriate to distinguish among studies that address the sustainability assessment of macro-systems (e.g., a region, state, country or policy) and papers that carry out the same assessment at the company/supply chain level. The former group of studies (e.g., $[12,16,18,19,40,41])$ has a limited relationship with the present paper. Indeed, our chosen context of analysis is quite different, as we focus on the evaluation of the sustainability level at the company/corporate level. It is hard to transfer indexes and metrics used to assess the sustainability level of a state or country to the case of a company. Similarly, the benchmark required for the evaluation of sustainability in the two contexts is completely different. Therefore, in line with the scope of our research, we focused our review on the works that considered all three perspective of sustainability and that either carry out the assessment of sustainability in a company/supply chain or propose the use of fuzzy logic for sustainability assessment.

Among the different models that can be used for the analysis of sustainability [42], we targeted quantitative models, because of their capability to measure and compare the various aspects of sustainable development. Examples of these models include simulation models [43], economic models [44], policy-endorsed quantitative models [45] and fuzzy logic-based models [19]. Hassini et al. [46] described the key supply chain processes to be considered when evaluating the sustainability of a company, i.e., sourcing, transformation and delivery. They also reviewed the available literature with the purpose of deriving suitable performance indexes for each process and finally provided a quantitative assessment of sustainability in a real context. Ahi and Searcy [47] carried out a detailed review of 445 papers, with the purpose of identifying the main indexes for sustainability assessment according to its three perspectives. The authors found 2555 unique metrics, the majority of which appeared only once in the literature; environmental indexes (e.g., energy use or greenhouse gas emissions) were found to be the most popular metrics adopted by researchers. Wilson [48] explored the application of the three pillars of sustainability in the context of a main retailer, through a case study-based research. Tajbakhsh and Hassini [49] proposed a data envelopment analysis (DEA) model for the evaluation of sustainability of supply chain operations, from the economic, environmental and social perspectives. They applied their model to two companies, operating in the manufacturing sector and in the service one. Mota et al. [50] proposed a multi-objective mathematical programming model designed to address the general issue of supply chain design and planning, but that, at the same time, integrates the three pillars of sustainability. From an economic perspective, the authors considered the total costs of the supply chain, while, from an environmental one, they made use of an environmental assessment methodology. Finally, the social perspective was addressed by means of ad hoc indicators, which capture the social and political concerns of the company. Chen and Andresen [51] carried out a similar work by developing a multi-objective programming model, which jointly minimizes costs, emissions and employee injuries in a supply chain. The analytic hierarchy process (AHP) is used to set the weights of the three objectives before solving the model and then to normalize the related outcomes. Ahi and Searcy [52] proposed a mathematical model for assessing sustainability in a supply chain, based on a probabilistic representation of sustainability. The model takes into account enablers and barriers to sustainability and is conceived of to quickly provide feedback on the sustainability status of supply chains over time.

The use of fuzzy logic for the assessment of sustainability was originally suggested by Phillis and Andriantiatsaholiniaina [38] and Andriantiatsaholiniaina et al. [39], who evaluated the sustainability level of countries and developed an approach, called SAFE (sustainability assessment by fuzzy evaluation), which includes indexes specific to this particular context. Examples of the evaluation of the company's sustainability through fuzzy logic can be found in $[40,53,54]$. Sabaghi et al. [40] developed a fuzzy-inference system to evaluate product/process sustainability. Fuzzy AHP, coupled with the Shannon's entropy formula, was used to determine the relative importance of each element in the hierarchy. The proposed methodology has been designed expressly for the evaluation of the sustainability of a product or manufacturing strategy and therefore covers only a specific facet of 
the sustainability of a company/supply chain. Kouikoglou and Phillis [53] have proposed a model that uses hierarchical fuzzy reasoning to assess corporate sustainability, focusing on the social and environmental perspectives, starting from a number of inputs. The model is applied to two case studies referring to as many companies operating in the cement industry. Phillis and Davis [54] have developed a multi-stage fuzzy reasoning model, which was presented to assess a corporation's sustainability. The model includes both human and ecological components. Human components embody the economic, political, knowledge and welfare perspectives, while the ecological component involves inputs related to air, water, land and biodiversity. A typical property of models that make use of fuzzy logic is monotonicity: this means that the aggregate measure should increase whenever one of its inputs improves, all others being constant.

The present paper takes inspiration from the works that applied fuzzy logic (and monotonic fuzzy inference models in particular) to the assessment of the company's sustainability. At the same time, the paper goes beyond the existing literature in the following ways:

- It develops a monotonic hierarchical fuzzy inference tool that allows assessing the sustainability at the corporate level, taking into account its three key perspectives, i.e., the economic, environmental and social aspects;

- it suggests a set of indexes useful to assess sustainability according to the perspectives listed above, along with their computational procedure;

- it solves some issues related to the definition of the scales and benchmark for the evaluation of the company's performance against each sustainability index, thus allowing the DM to evaluate how a company is close to or far from a target value;

- it embodies the fuzzy inference model in a Microsoft Excel ${ }^{\mathrm{TM}}$ software ((Microsoft Corporation, Albuquerque, NM, USA) tool that makes the application of the framework straightforward and enables its practical use by DMs.

\section{The Methodological Approach}

The scheme followed to develop the model consists of three main steps and several sub-steps shown in Figure 1.

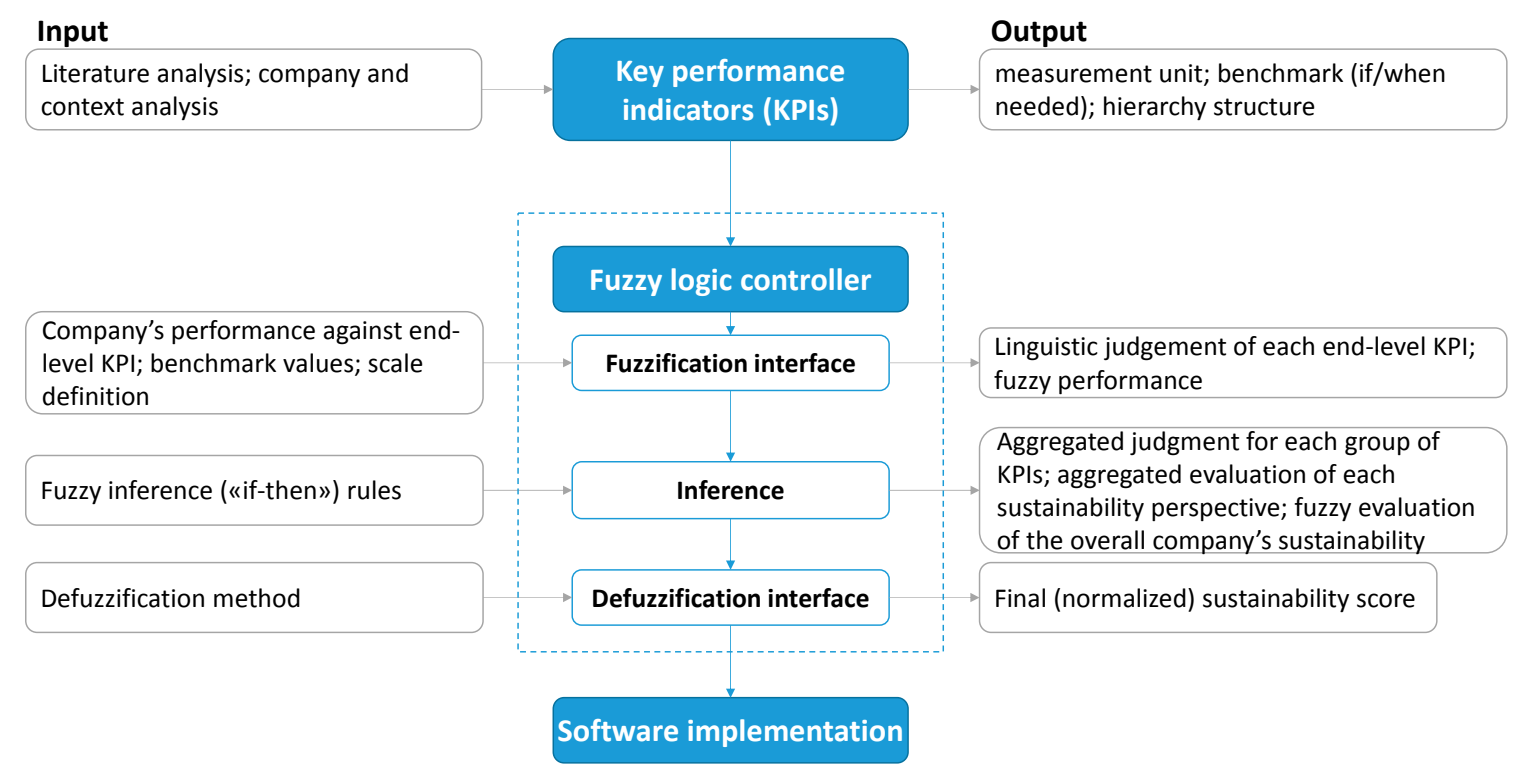

Figure 1. Scheme followed to develop the sustainability assessment model. 


\subsection{Key Performance Indicators}

The first step for developing the assessment tool consists of the identification of the suitable indexes for sustainability evaluation. The following sub-steps are required:

1. Choosing the appropriate KPIs;

2. Identifying a proper measurement unit for each KPI;

3. Evaluating the need for a benchmark for each KPI;

4. Aggregating the KPIs into a hierarchy structure.

With respect to Sub-steps (1) and (2), we have recalled earlier that identifying all of the key aspects of sustainability is not trivial [31]. Nonetheless, the available literature offers several studies that list and describe useful KPIs for sustainability assessment at the company or supply chain level (e.g., $[47,48,55,56])$. These studies were examined and used as the basis to derive a set of KPIs for sustainability evaluation, focusing on performance indexes suitable for a quantitative assessment; these indexes are summarized in Table 1, together with a suitable computational procedure. In the same table, we have also reported the source from which each KPI was derived. The list of KPIs in Table 1 should be regarded as a proposal of metrics and indexes for sustainability assessment at the corporate level, but cannot be claimed to be exhaustive or of general validity. Rather, it is reasonable to expect that depending on the case under examination, some KPIs could be removed (because they are not relevant for the specific context or company) or added, with the purpose of capturing peculiar aspects of sustainability. We will discuss this point in the case study section.

Sub-step (3) will be addressed in the case study section, as well, as the need for a benchmark chiefly depends on the KPIs selected for a specific company and on the chosen measurement unit.

With respect to Sub-step (4), the aggregation of KPIs in a hierarchical structure helps make the application of the fuzzy inference tool more straightforward. Figure 2 shows a possible aggregation of the KPIs listed in Table 1. It should be remarked that, although Figure 2 shows the aggregation of two KPIs at a time (for the sake of simplicity), the proposed approach can be easily extended to the aggregation of more inputs, as also confirmed by the studies available in the literature [54,55]. Indeed, the way inputs should be aggregated is ultimately a choice of the DM, it being understood that the combination of KPIs should be always supported by some logic. 
Table 1. Proposal of KPIs for the assessment of the company's sustainability.

\begin{tabular}{|c|c|c|}
\hline Sustainability Perspective & KPIs and Source & Description and Computational Procedure \\
\hline \multirow[t]{16}{*}{ Economic } & Delivery flexibility [56] & Ratio between the number of times the request to change the date for delivery is satisfied and the total requests \\
\hline & Mix flexibility [57] & Ratio between the number of times the request to change the mix is satisfied and the total requests \\
\hline & Customization [57] & Ratio between the number of times the request of personalization is satisfied and the total requests \\
\hline & Warehouse turnover rate [58] & $\begin{array}{l}\text { Number of times per month where the items rotate, i.e., they are replaced in the warehouse; the higher the } \\
\text { number of rotations, the higher the capacity of the company to recover the financial resources invested in the } \\
\text { production of the good }\end{array}$ \\
\hline & Rate of defects [47] & $\begin{array}{l}\text { Ratio between the number of non-compliant products and the total number of products; it provides a measure } \\
\text { of the quality of the company }\end{array}$ \\
\hline & Rate of multiple-sourcing [59] & $\begin{array}{l}\text { Percentage of supplies for which a multiple-sourcing strategy is adopted; this KPI evaluates the risk of a } \\
\text { supplier's failure: the higher is the number of different suppliers, the lower is the risk of the supplier's failure }\end{array}$ \\
\hline & Customer satisfaction [47] & It measures the extent to which the product supplied by a company meets the customer's expectation \\
\hline & Out-of-stock [60] & Number of days per year in which the company does not have goods available to sell to the final customer \\
\hline & Sales growth [47] & It reflects the increase in the company's sale compared to the previous year \\
\hline & Market share [47] & The share of the company's sales compared to the total market's sales \\
\hline & Return on investment (ROI) [47] & $\begin{array}{l}\text { It is a financial performance referring to the company's balance sheet, computed as the ratio between the net } \\
\text { income and the amount of capital invested }\end{array}$ \\
\hline & Turnover [61] & Company's annual turnover \\
\hline & Cost of sales [61] & Total cost of the items manufactured and sold; it is derived from the company's balance sheet \\
\hline & Inventories [46] & Economic value of the amount of stocks; it is derived from the company's balance sheet \\
\hline & Investments in $\mathrm{R} \& \mathrm{D}[47,61]$ & Amount of capital invested in R\&D annually by the company \\
\hline & Net profit [47] & It is a measure of the company's profitability and is taken from the company's balance sheet \\
\hline \multirow[t]{5}{*}{ Environmental } & Eco-design [62] & Percentage of products realized applying environmentally-sustainable design concepts \\
\hline & Carbon footprint [47] & $\begin{array}{l}\text { Amount of greenhouse gas emission of the products manufactured by the company; it is typically obtained as } \\
\text { the output of a life-cycle assessment (LCA) analysis }\end{array}$ \\
\hline & Energy footprint [63] & $\begin{array}{l}\text { Measure of land required to absorb the } \mathrm{CO}_{2} \text { emissions of a product manufactured by the company; it is } \\
\text { typically obtained as the output of an LCA analysis }\end{array}$ \\
\hline & Water consumption [47] & Amount of freshwater taken from ground or surface sources \\
\hline & Air emissions [47] & Amount of pollutants released into the atmosphere \\
\hline
\end{tabular}


Table 1. Cont

\begin{tabular}{|c|c|c|}
\hline Sustainability Perspective & KPIs and Source & Description and Computational Procedure \\
\hline & Use of hazardous materials [64] & Amount of hazardous, harmful or toxic material used in production \\
\hline & Product recycling rate [65] & Percentage of finished products recycled \\
\hline & Product non-recycling rate [65] & Percentage of finished products discharged \\
\hline & Packaging recycling rate [66] & Percentage of packaging material recycled \\
\hline & Packaging non-recycling rate [66] & Percentage of packaging material disposed in landfill \\
\hline & Unitary transport cost [28] & Unitary cost associated with the transport activities \\
\hline \multirow[t]{13}{*}{ Social } & Work shift [47] & Average number of hours worked per week by an employee \\
\hline & Salary [1] & Average annual cost per employee \\
\hline & Employment gender ratio [67] & Percentage of female workers with respect to male workers \\
\hline & Job training [68] & Percentage of workers who attended training courses \\
\hline & Full-time workers [67] & Percentage of full-time workers out of the total amount of employees \\
\hline & Temporal working continuity [69] & Ratio between the number of new hired workers and of layoffs in one working year \\
\hline & Safety training [68] & Percentage of workers who attend training courses on safety and emergency procedures \\
\hline & Work injury [51] & Ratio between the number of days in which work injuries occurred and the total number of working days \\
\hline & Local suppliers [70] & Ratio between the number of local suppliers and the total number of suppliers \\
\hline & Local workers [70] & Ratio between the number of local workers and the total number of employees \\
\hline & Claims [47] & Number of complaints received from the customers out of the total number of customers served \\
\hline & $\begin{array}{l}\text { Supplier's screening } \\
\text { for human rights [71] }\end{array}$ & Percentage of suppliers evaluated on the respect for human rights \\
\hline & Sustainable suppliers [71-73] & $\begin{array}{l}\text { Percentage of suppliers that are evaluated and selected taking into account their orientation } \\
\text { towards sustainability }\end{array}$ \\
\hline
\end{tabular}




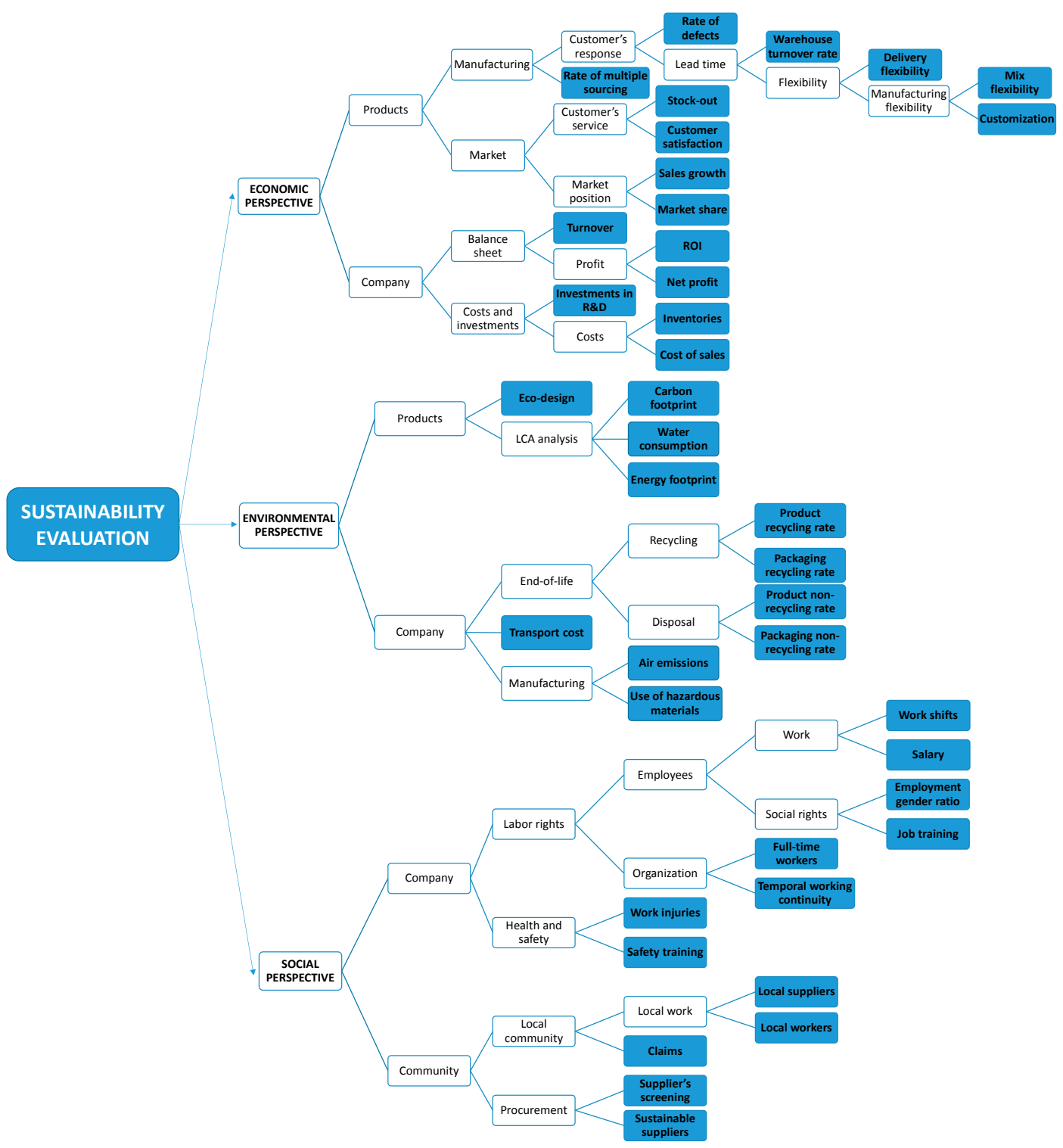

Figure 2. Proposal of the hierarchy structure of the KPIs in Table 1.

\subsection{Design of the Fuzzy Inference Tool}

A fuzzy inference tool works with a set of heuristic decision rules expressed in linguistic terms [74-77] and typically consists of three main components, described in the subsections that follow.

\subsubsection{Fuzzification Interface}

A fuzzification tool turns the numerical inputs into linguistic variables by means of suitable membership functions, which should be properly defined to obtain a meaningful evaluation. The fuzzification process is to be applied to all of the end-level KPIs used for the assessment of the company's sustainability. With reference to the proposal of the indexes in Table 1, end-level KPIs are highlighted in blue in Figure 2.

The following sub-steps are required to complete the fuzzification:

1. Measuring the company's performance against the end-level KPIs;

2. Retrieving the benchmark values;

3. Setting the fuzzy linguistics scales. 
In Sub-step (1), the DM should get a quantitative score that expresses the company's performance against each end-level KPI, according to its measurement unit. With respect to Sub-step (2), whenever the KPI requires a benchmark to be evaluated in a meaningful way, the reference value should also be retrieved. As an example, the best competitor can represent a useful benchmark to rate the company's performance; for some KPIs, official benchmarks might also be available.

As far as Sub-step (3) is concerned, the DM needs to define specific scales for each end-level KPI, to turn the company's performance into a fuzzy number. No general scales can be defined at this stage, because of the differences that can exist among diverse companies and market fields evaluated. Rather, the fuzzification scales need to be tuned anytime a new company is being evaluated or new KPIs are included in the assessment. Besides this practical aspect, from a technical perspective, different kinds of scales can be used when dealing with fuzzy numbers, although Chen and $\mathrm{Ku}$ [75] found that most of the times, researchers make use of 4-point or 5-point linguistic scales. In addition, triangular or trapezoidal fuzzy numbers can be used almost indifferently to translate the linguistic judgements into fuzzy values [75]; therefore, in practical cases, these decisions are left to the DM.

To illustrate the framework and its software implementation, we suppose that a 4-point linguistic scale (very good, VG; good, G; poor, P; and very poor, VP) is used to rate the company's performance against the end-level sustainability KPIs and that trapezoidal membership functions are adopted. The mathematical definition of trapezoidal fuzzy numbers is the following [73]:

$$
\mu(x)= \begin{cases}0 & \text { if } x<a \\ \frac{x-a}{b-a} & \text { if } a \leq x \leq b \\ 1 & \text { if } b \leq x \leq c \\ \frac{x-d}{c-d} & \text { if } c \leq x \leq d \\ 0 & \text { f } x>d\end{cases}
$$

where $x$ denotes the numerical value of the variable, $\mu(x)$ the corresponding membership degree, and $a, b, c$ and $d$ the numerical values that describe the shape of the trapezoidal fuzzy number.

Let us consider, as an example, the end-level KPI "Mix flexibility", i.e., the ratio between the number of times the request to change the mix is satisfied and the total requests (Table 1). It is reasonable to expect that its numerical value will be expressed as a percentage in the [0-1] range, with the target (benchmark) being $100 \%$ (the higher the better). Translating this range into a fuzzy scale is relatively easy, with the only issue being the definition of the shape of the trapezoidal fuzzy number $(a, b, c$ and $d)$. Let us suppose that, based on his/her experience and knowledge of the specific context or based on scales available in the literature [38,73], the DM has defined the trapezoidal fuzzy numbers as follows:

- VP: between $0 \%$ and $25 \%$, with $\mu(x)=1$ if $0 \leq x \leq 0.2$;

- P: between $20 \%$ and $50 \%$, with $\mu(x)=1$ if $0.25 \leq x \leq 0.45$;

- $\mathrm{G}$ : between $45 \%$ and $75 \%$, with $\mu(x)=1$ if $0.5 \leq x \leq 0.7$;

- VG: between $70 \%$ and $100 \%$, with $\mu(x)=1$ if $x \geq 0.75$.

As mentioned, "Mix flexibility" is an example of a KPI whose numerical value is expressed as a percentage in the [0-1] range. Anytime a KPI can be expressed in this range, it is reasonable to expect that either a "the lower the better" or a "the higher the better" logic applies. The benchmark, therefore, is automatically defined, being 0 in the former case and 1 in the latter one. On the contrary, whenever a KPI cannot be measured on a [0-1] scale (as for the case, e.g., of the company's turnover), the DM should also retrieve a benchmark (e.g., the best competitor performance) to compare the company's score with a target value. Obviously, the DM could also need to redefine the linguistic scale to be used in the fuzzification interface. 


\subsubsection{Inference}

The inference is a decision process that takes as inputs the fuzzy numbers obtained from the fuzzification interface and generates as output a new fuzzy set, with a corresponding degree of membership, called the "truth value" of the rule. The process is based on a series of "if-then" rules that link fuzzy inputs and outputs, in the following way:

\section{IF $x$ is $A$ AND $y$ is $B$ (premises) THEN $z$ is $C$ (conclusion)}

where $A, B$ and $C$ are the linguistic values defined by fuzzy sets on the universe of analysis $X, Y$ and $Z$, respectively. By inference of these rules, the conclusions can be drawn through fuzzy reasoning and by means of fuzzy implication functions (for further details, see [76,77]).

The following sub-steps should be carried out:

1. Setting the fuzzy inference rules to aggregate the KPIs iteratively;

2. Computing the overall sustainability.

Starting from Sub-step (1), the inference process is to be applied anytime two (or more) KPIs should be combined to derive an aggregated performance index, which allows moving from the end-level KPIs upstream in the hierarchy structure of Figure 2. Let us consider the case of two end-level KPIs, e.g., "Mix flexibility" and "Customization", whose score should be aggregated. Both KPIs have been previously evaluated on a 4-point linguistic scale; however, when aggregating them in the inference process, it could be appropriate to introduce a fifth judgment (average, A) to describe intermediate situations where the company's performance against the two KPIs is conflicting. If a new judgement is added, the linguistic scale should obviously be redefined; an example is provided below:

- VP: between $0 \%$ and $20 \%$ with $\mu(x)=1$ if $x \leq 0.15$;

- P: between $15 \%$ and $40 \%$ with $\mu(x)=1$ if $0.20 \leq x \leq 0.35$;

- A: between $35 \%$ and $60 \%$ with $\mu(x)=1$ if $0.40 \leq x \leq 0.55$;

- G: between $55 \%$ and $80 \%$ with $\mu(x)=1$ if $0.60 \leq x \leq 0.75$;

- VG: between $75 \%$ and $100 \%$ with $\mu(x)=1$ if $x \geq 0.80$.

Figure 3 shows an example of if-then rules that can be adopted to aggregate two end-level KPIs in the inference process, assuming that the same relative importance has been assigned to "Mix flexibility" and "Customization". Obviously, this is once again a choice of the DM, who could also decide on a different balance between the two KPIs.

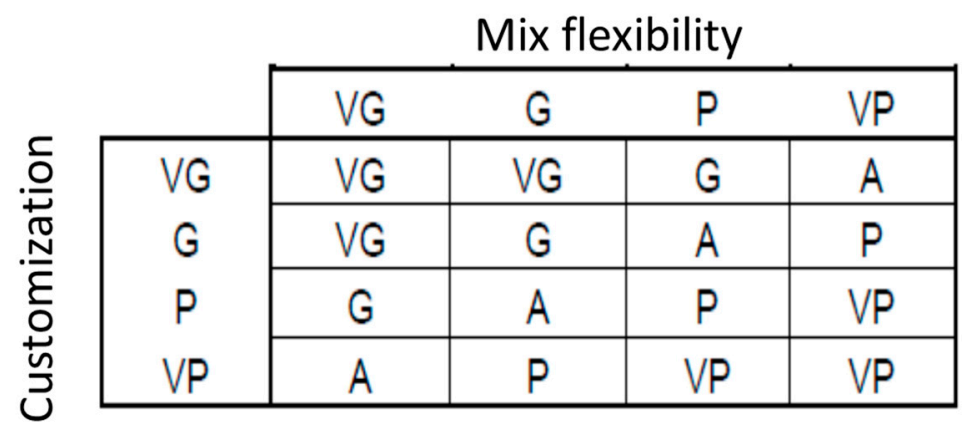

Figure 3. Example of if-then rules for the inference process with two end-level KPIs. VG, very good; G, good; P, poor; VP, very poor; A, average.

Because the result of the aggregation of two end-level KPIs is expressed on a 5-point scale, when aggregating performance judgements at a higher level of the hierarchy, both inputs will be expressed 
on a 5-point scale. This implies that additional if-then rules should be formulated; a set of possible rules is shown in Figure 4, assuming again the same importance of both performance judgements.

Performance Judgement \#1

\begin{tabular}{|c|c|c|c|c|c|c|}
\hline \multirow{6}{*}{ 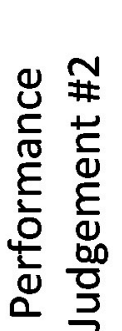 } & & VG & $G$ & A & $P$ & VP \\
\hline & VG & VG & VG & $G$ & $G$ & $A$ \\
\hline & $G$ & VG & $G$ & G & $\mathrm{A}$ & $P$ \\
\hline & A & $G$ & $G$ & A & $\mathrm{P}$ & $P$ \\
\hline & $P$ & $G$ & $\mathrm{~A}$ & $P$ & $P$ & VP \\
\hline & VP & A & $P$ & $\mathrm{P}$ & VP & VP \\
\hline
\end{tabular}

Figure 4. Example of if-then rules for the inference process for non-end-level KPIs.

Further situations that can occur during the inference process are:

- the aggregation of an end-level KPI (4-point scale) with a performance judgement at a higher level of the hierarchy (5-point scale); in this situation, the rules proposed in Figure 4 can still be adopted, provided that the A judgement is neglected for one of the inputs; or

- the aggregation of more than two end-level KPIs; this means that further rules should be designed; some examples of these rules can be found in $[39,55]$.

As mentioned earlier in the paper, monotonicity is a typical and desirable property of aggregation mechanisms; to ensure monotonicity, in the proposed approach we adopted the hierarchical sum-product inference process [78]. According to this method, the logical operator AND that connects the premises of an inference rule is represented algebraically by the product of the individual truth values. If more than one rule returns the same linguistic judgement as the conclusion, its overall membership degree is obtained as the sum of the individual truth values.

The process described above should be applied until three performance judgements (along with the related fuzzy numbers) are obtained for the economic, environmental and social sustainability perspectives. With these values, the overall sustainability of the company can be evaluated (Sub-step (2)). However, because of the presence of three inputs, combining the economic, environmental and social performance requires a slight adjustment of the inference rules, which should be modified as follows:

IF economic perspective is $K$ AND environmental perspective is $J$ AND social

perspective is $Q$ (premises) THEN company's sustainability is $Z$ (conclusion)

This situation can be addressed, once again, designing more rules (125 in total); useful examples are available in $[39,55]$.

\subsubsection{Defuzzification Interface}

The defuzzification process consists of replacing the fuzzy set(s) with a corresponding crisp value. Two sub-steps are required, i.e.,

1. choosing the defuzzification method;

2. normalizing the final score.

As far as Sub-step (1) is concerned, Van Leekwijck and Kerre [79] found that one of the most used defuzzification procedure is the fuzzy mean (FM) method, because of its simplicity and effectiveness. The FM defuzzification method consists of the application of the following formula:

$$
F M=\frac{\sum_{k=1}^{F C} \alpha_{k} x_{k}}{\sum_{k=1}^{F C} \alpha_{k}}
$$


In Equation (2), FC represents the number of fuzzy conclusions, and $\alpha_{k}$ is the truth value of conclusion $k$ as it results from the inference. $x_{k}$ is the numerical value associated with the $k$ th conclusion, which is assumed to be the numeric value at which the $k$ th membership function reaches its maximum (for trapezoidal fuzzy numbers, the average between the two boundaries where the membership degree is maximum is taken).

The crisp value obtained through the FM method is useful to compare the performance of different companies in terms of sustainability and to rank them. However, the crisp value obtained at this stage and its range of variation depend on the type of fuzzy numbers and scales used. Hence, a final normalization (Sub-step (2)) could be appropriate to get an output ranging from zero to one (the higher the better). The following formula can be used to this end:

$$
\text { Normalized Value }=\frac{(x-\min )}{(\max -\min )}
$$

where $x$ is the crisp value of the sustainability index before normalization and $\min$ and $\max$ are the lowest and highest boundaries of its range of variation, respectively. min and max reflect the extreme situations where the company's performances all score the lowest or highest value of the linguistic scale.

\subsection{Software Implementation}

The fuzzy inference tool described in the previous subsections was implemented under Microsoft Excel $^{\mathrm{TM}}$ to develop a user-friendly software that can be exploited by a DM to evaluate the sustainability level of his/her company. Appropriate macros were programmed in Visual Basic for Applications (VBA) to carry out recurring operations, such as fuzzification and inference, as well as to help process a wide amount of fuzzy numbers, which obviously increases the computational complexity.

The Microsoft Excel ${ }^{\mathrm{TM}}$ file consists of four spreadsheets (Figure 5). The three key sustainability perspectives are analyzed separately in Spreadsheets 1-3. Each spreadsheet embodies the hierarchy structure of the perspective and the inference rules to aggregate the related KPIs. Because the procedures and functions implemented in Spreadsheets 1-3 are the same for each perspective, for the sake of brevity, their description in Sections 3.3.1-3.3.2 is limited to the economic perspective of sustainability. The evaluation of the overall sustainability level is carried out in Spreadsheet 4, whose functioning is described in Section 3.3.4.

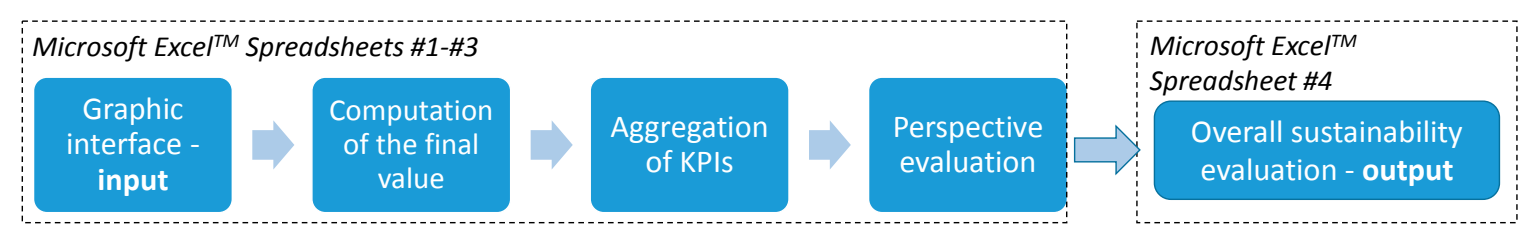

Figure 5. Scheme of the Microsoft Excel ${ }^{\mathrm{TM}}$ tool for sustainability assessment.

\subsubsection{Graphical Interface: Input}

The first element of each spreadsheet is a graphic, user-friendly, interface where the DM can insert the input data, i.e., the end-level KPIs that will be used to evaluate the company's sustainability. The software tool is pre-programmed with the list of end-level KPIs proposed in Table 1; for each KPI, the DM should first decide whether to retain it in its original form, adapt it to the chosen context of analysis or remove it. Should a KPI be retained (either in its original form or with modifications), the DM will be asked to enter the following input data:

- the numerical values reflecting the scores of the company against the KPI, expressed in the appropriate measurement unit;

- $\quad$ the indexes to which the KPI should be aggregated in the hierarchy structure; 
- the benchmark values (if/when required) and the way the comparison with the benchmark should be made (e.g., ratio, percentage difference, etc.);

- the type of fuzzy linguistic scales and fuzzy numbers to be used in the fuzzification interface.

Moreover, the user can set the relative importance of the elements processed by fuzzy if-then rules in the inference.

\subsubsection{Computation of the "Final Score"}

On the basis of the scores of the company against the end-level KPIs, the benchmark values and the way the comparison with the benchmark should be made, the software tool computes a "final score" for each end-level KPI. This crisp value compares the performance of the targeted company to the benchmark value. The steps listed in Figure 6 have been implemented in Microsoft Excel ${ }^{\mathrm{TM}}$ to automate the computation of the "final score".

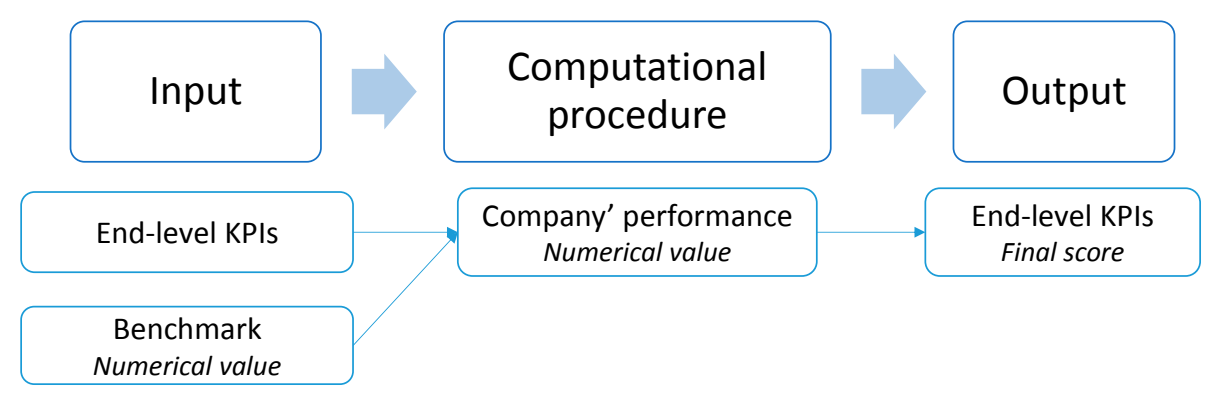

Figure 6. Steps for the computation of the "final score" in Microsoft Excel ${ }^{\mathrm{TM}}$.

Whenever the comparison with the benchmark is not required, the "final score" directly reflects the input entered by the DM. Otherwise, it is computed by comparing the company's performance to the benchmark, according to the computational procedure chosen by the user (e.g., as the ratio between the input value and the benchmark). Figure 7 shows an example of input data entered by the user and of "final score" returned by the proposed tool.

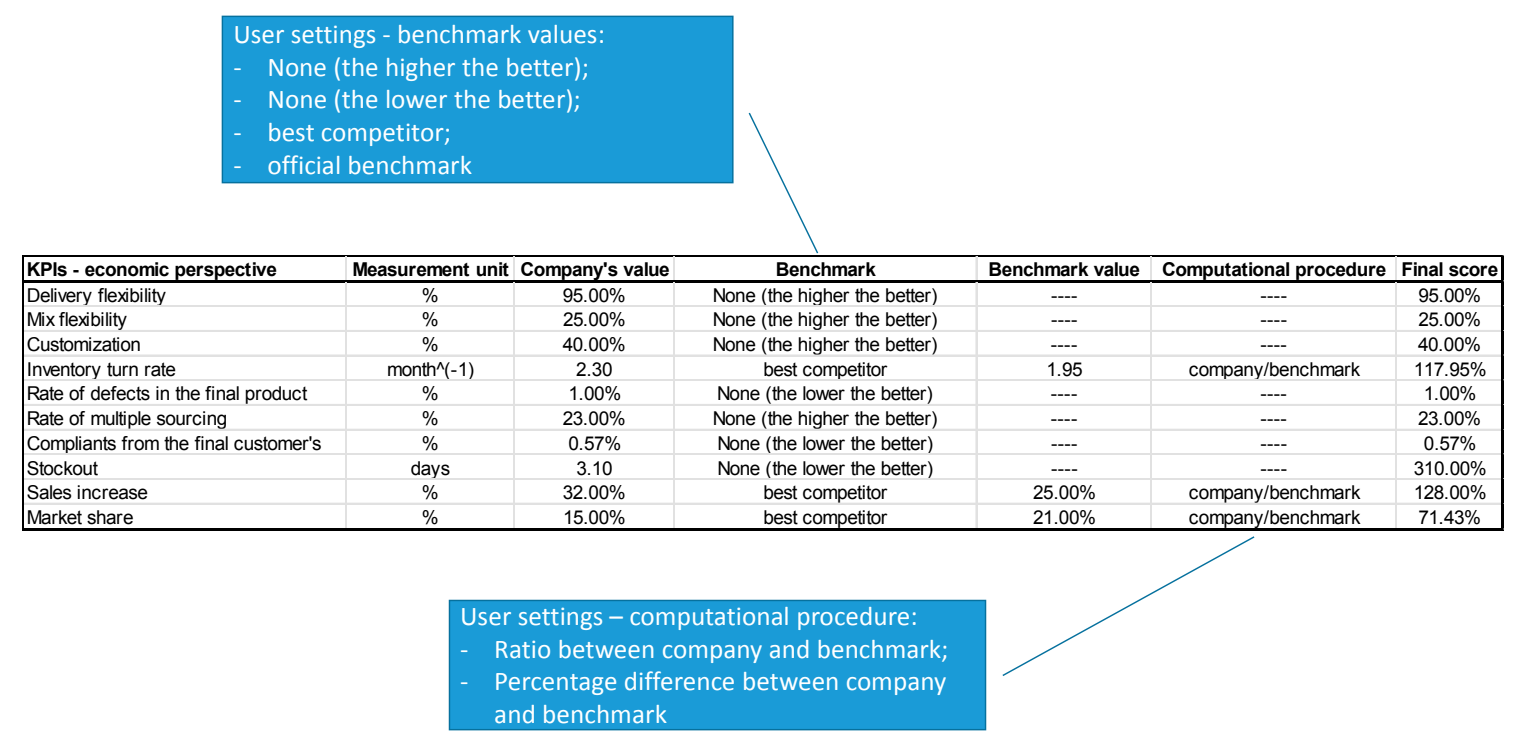

Figure 7. Graphical interface implemented under Microsoft Excel ${ }^{\mathrm{TM}}$. 


\subsubsection{Aggregation of KPIs}

As already recalled, indexes should be subsequently aggregated starting from the end-level KPIs, following the hierarchy structure defined by the user. The software tool allows the user to choose up to three KPIs to be aggregated at each level of the hierarchy structure to build the decision model, starting from the end-level KPIs retained.

Figure 8 lists the steps implemented in Microsoft Excel ${ }^{\mathrm{TM}}$ to automate the aggregation of the KPIs. For simplicity, the figure and related description refer to the aggregation of two KPIs.

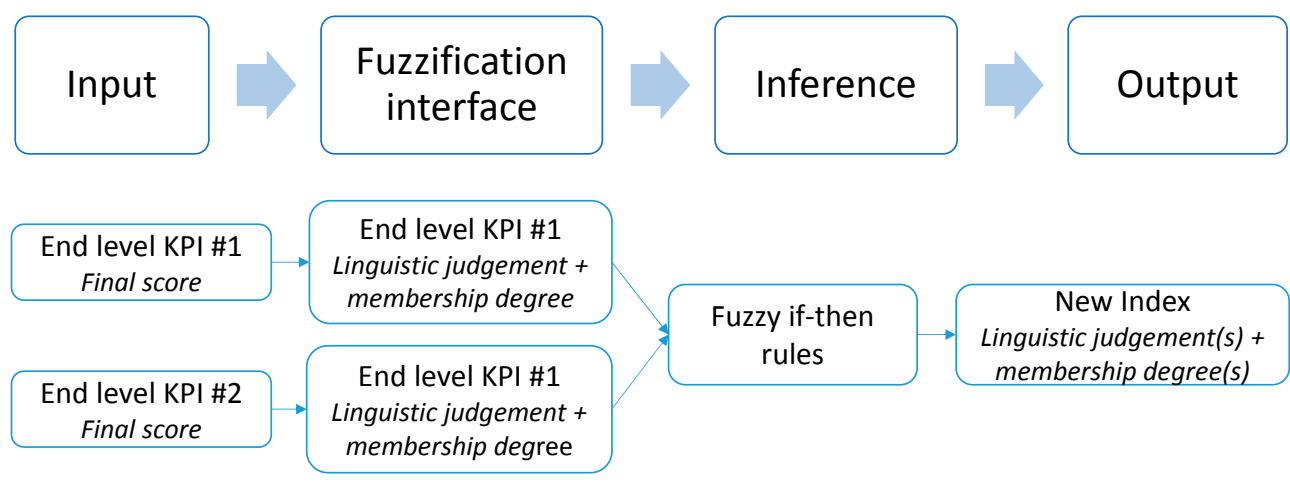

Figure 8. Steps for the aggregation of the KPIs under Microsoft Excel ${ }^{\mathrm{TM}}$.

The input of the aggregation is the final score of each KPI, as it results from the computation made in the previous step. This value is translated into linguistic variables, using the scale set by the user: as an example, Figure 9 shows the user settings and the fuzzification process of a generic economic KPI. In this example, the user has selected a 4-point scale (from VP to VG) with trapezoidal fuzzy numbers, whose definition reflects those available in the literature [38,73].

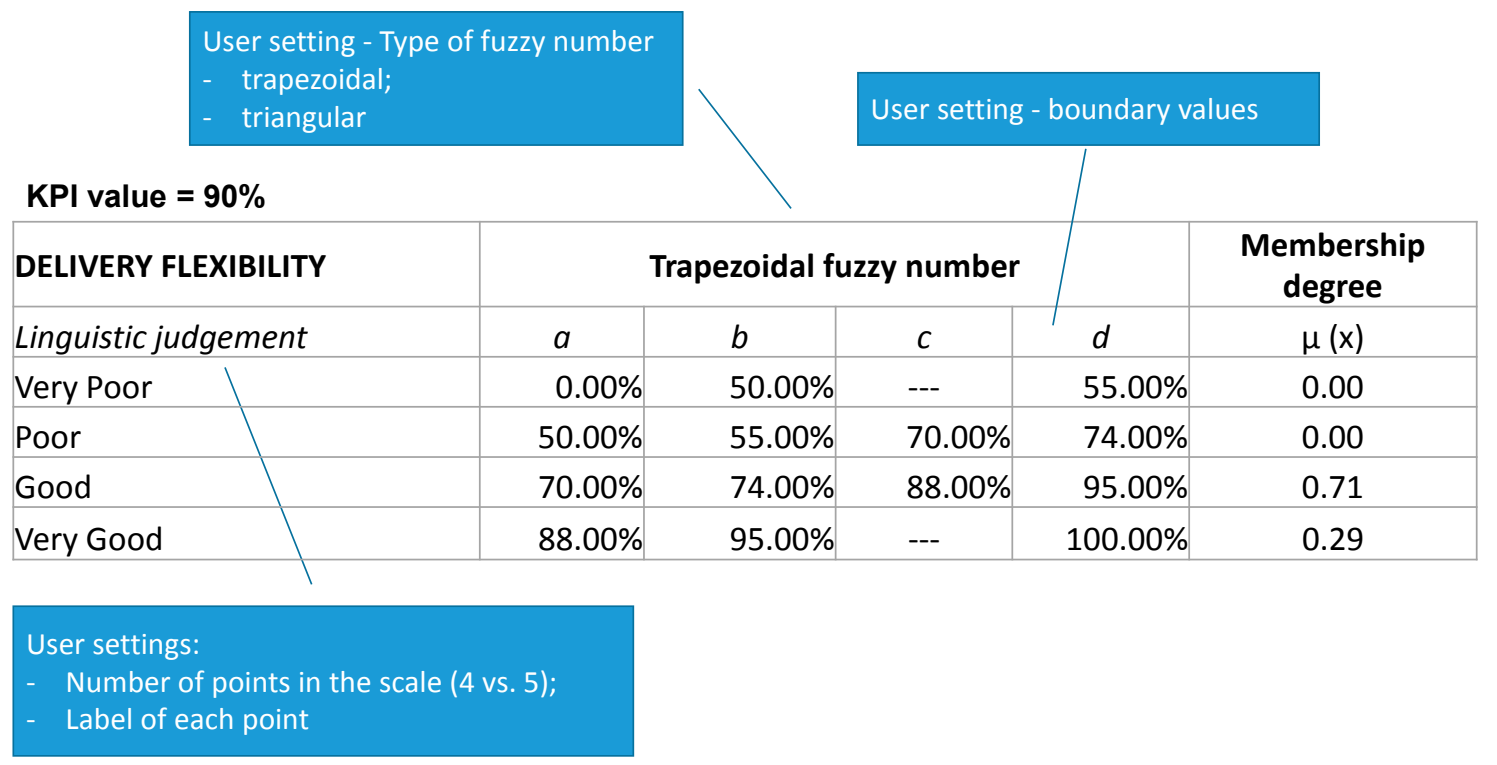

Figure 9. Example of fuzzification under Microsoft Excel ${ }^{\mathrm{TM}}$.

The next step is to aggregate the two KPIs by applying the fuzzy if-then rules, which allow the DM to derive a "new index". The fuzzy if-then rules described in Section 3.2.2 have been programmed into appropriate VBA macros to recall them in an automated way. Different code modules have been encoded to generate the inference rules to aggregate the end-level KPIs, the "new indexes" or a 
combination of them (i.e., a KPI and a "new index"). By default, the if-then rules assume the same importance level for each element aggregated in the inference process; otherwise, the user can set a different importance value for one of the KPIs to be aggregated.

Figure 10 provides an example of the aggregation of two end-level KPIs as it is performed in Microsoft Excel ${ }^{\mathrm{TM}}$. The company's performance against the two KPIs (left part of Figure 10) has been judged as follows:

- $\quad \mathrm{KPI} \# 1=\mathrm{P}$ with $\mu(x)=0.5$ and $\mathrm{G}$ with $\mu(x)=0.5$;

- $\quad \mathrm{KPI} 2=\mathrm{P}$ with $\mu(x)=0.6$ and $\mathrm{G}$ with $\mu(x)=0.4$.

The inference process should consider all possible combinations of judgements and membership functions of the two KPIs and activate the corresponding rules. The aggregation of KPI\#1 $=\mathrm{P}$ and $\mathrm{KPI} \# 2=\mathrm{P}$, which is exemplified in the figure, leads to a "new index" that is judged as $\mathrm{P}$, according to the inference rules previously shown in Figure 3. As far as the truth value of the new index is concerned, in the sum-product inference process, it is obtained as the product of the original membership functions, i.e., $0.5 \times 0.6=0.3$. The process is repeated for the remaining combinations of inputs, i.e.: $\mathrm{KPI \# 1}=\mathrm{P}$ and $\mathrm{KPI} 2=\mathrm{G} ; \mathrm{KPI} 1=\mathrm{G}$ and $\mathrm{KPI} 2=\mathrm{P} ; \mathrm{KPI} 1=\mathrm{G}$ and $\mathrm{KPI} 2=\mathrm{G}$. From the results obtained, it is easy to see that two combinations return an A judgement, with truth values 0.2 and 0.3 . Therefore, the final membership function of A for the "new index" is obtained as the sum of these two truth values.

The aggregation procedure should be run anytime two indexes should be combined, and therefore, it is applied iteratively moving upstream in the hierarchy of KPIs, until the linguistic judgement(s) and membership function(s) are obtained for the economic, environmental and social sustainability perspectives.

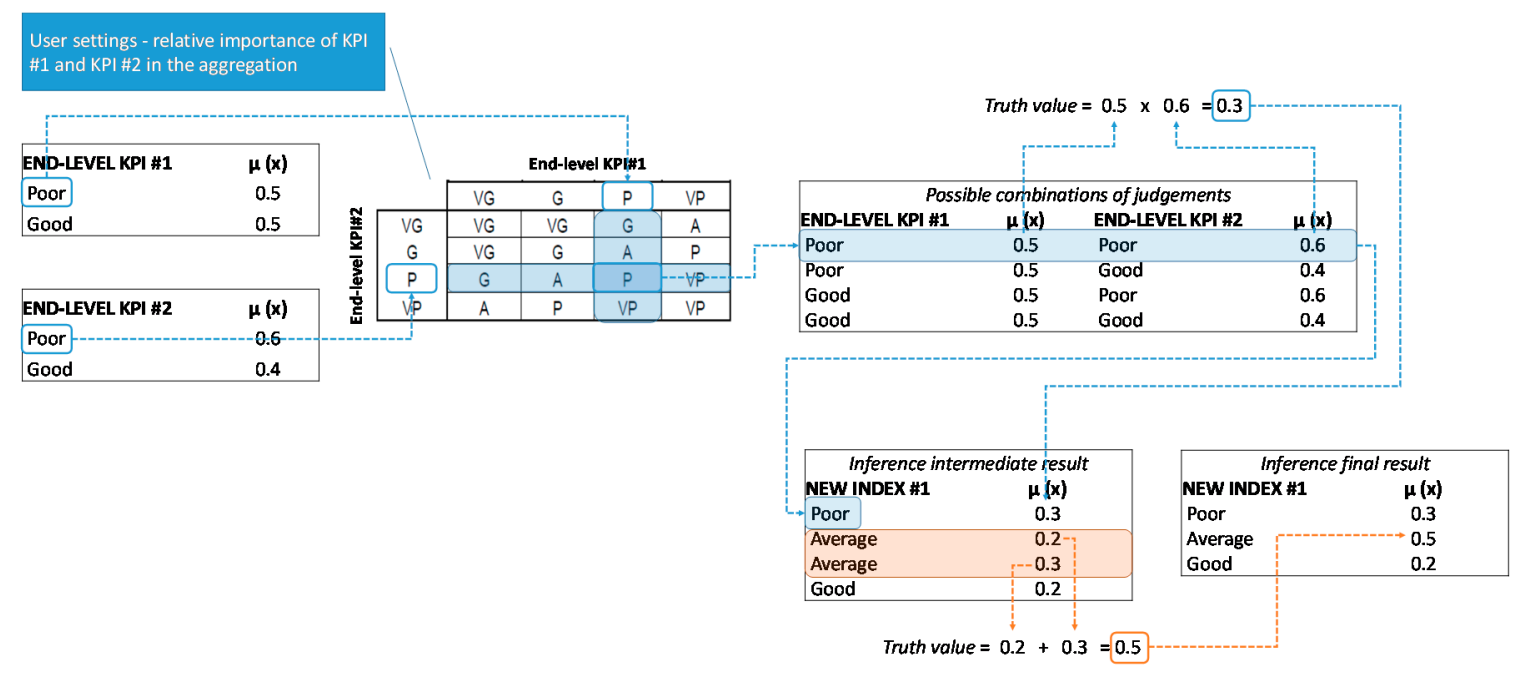

Figure 10. Example of inference rules for end-level KPIs under Microsoft Excel ${ }^{\mathrm{TM}}$.

\subsubsection{Overall Sustainability Evaluation: Output}

Spreadsheet \#4 (Figure 11) of the Microsoft Excel ${ }^{\mathrm{TM}}$ file takes as input the results of the evaluation of the three perspectives, aggregates them through inference and returns, as output, the overall sustainability evaluation of the company (defuzzification), which is finally subject to normalization to get a crisp value in the [0-1] range. 


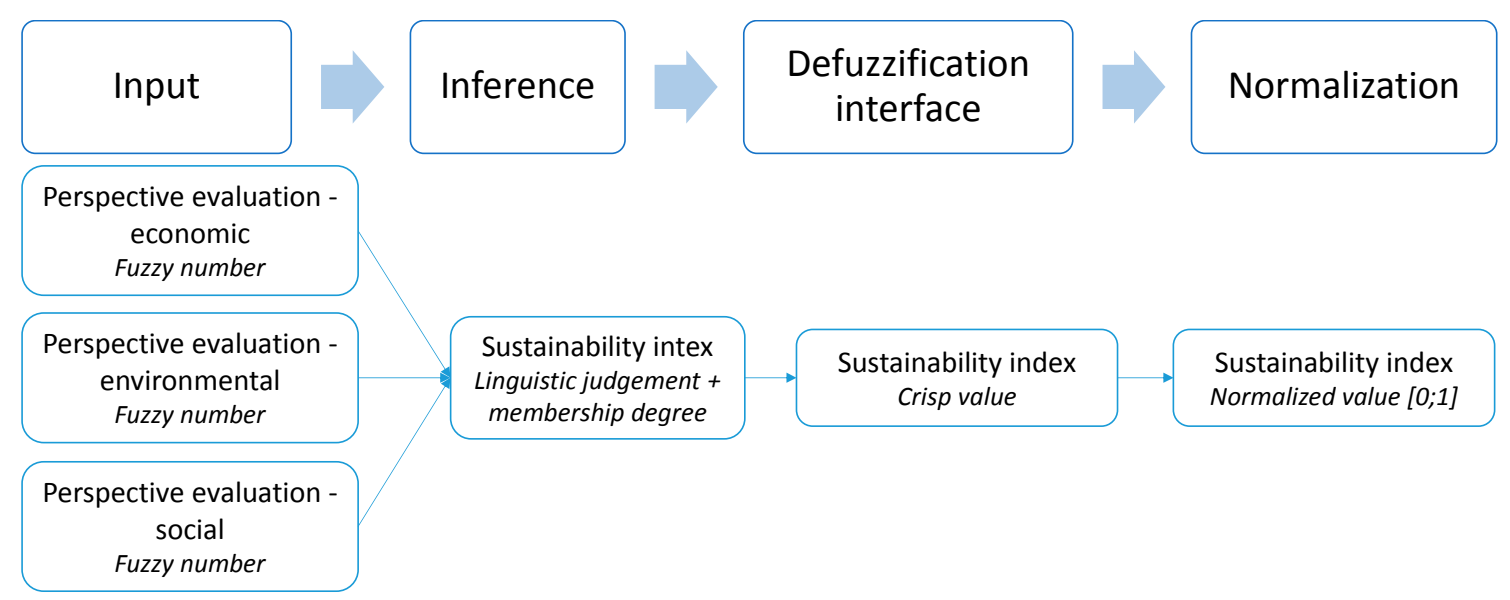

Figure 11. Steps for the computation of the sustainability index under Microsoft Excel ${ }^{\mathrm{TM}}$.

An appropriate VBA macro combines the three "perspective evaluations" exploiting almost the same procedure described in the previous subsection. The only main differences are that the scores will be all expressed on a 5-point linguistic scale, which makes the computational complexity higher (125 if-then rules). The output of the defuzzification interface is a synthetic score of the company's sustainability. This score is again computed assuming the same relative importance of each perspective, although the user can enter a different weight. The normalization step (Equation (3)) does not require any input by the user, as it takes as input $x$ as the crisp value of the sustainability index before normalization and computes min and max automatically, by setting the company's performance against all end-level KPIs at the lowest or highest value of the linguistic scale.

\section{Case Study}

\subsection{The Company}

The framework and software tool described in the previous section were tested on a case study company, which will be referred to as Company A for the sake of confidentiality. Company A is an Italian manufacturer of plants for the milling industry and exports its products to more than 147 countries. The company operates on an engineer-to-order (ETO) basis: any new product starts with the design of the plant and includes assembly, installation, civil works, test of the equipment at the customer's site and staff training. In Italy, Company A is leader in its market segment while, on a global basis, it ranks second among the top producers of milling plants.

\subsection{Preliminary Model Adaptation and Data Collection}

\subsubsection{Choice of the KPIs}

To apply the proposed framework to Company A, we started from the list of KPIs previously proposed in Table 1 and screened them carefully, to evaluate their relevance to the case under examination, taking into account the peculiarities of the company and of its market field. The screening process was carried out with the support of the company's top management: two managers from Company A, one from the manufacturing department and one from the financial area, were involved in this step of the implementation.

The company's managers received by email the list of KPIs derived from the literature (Table 1) and their aggregation into a hierarchy structure (Figure 2), as well as a list of the data required for the application of the model (e.g., the company's score against each KPI). The two managers were asked to evaluate the relevance of each KPI to the specific case of Company A, or, alternatively, to modify the KPIs, to adapt them to their company. The managers were interviewed between December 2015 
and January 2016, by means of phone calls, to gather their suggestions and formalize the list of KPIs considered as relevant for Company A. Table 2 lists the KPIs previously proposed in Table 1, specifying those that were used for the evaluation of Company A and those that were neglected. Possible adaptations are also detailed in the table; similarly, whenever a KPI was considered as non-relevant for Company A, the reason for its exclusion is described. Overall, 26 KPIs out of the initial list of 43 were considered relevant for the analysis. For these KPIs, the company's managers were asked to provide the corresponding score for Company A. These data were provided in March 2016. Out of the 26 KPIs included in the analysis, 13 did not require adaptations, while the remaining ones were modified either in their definition (e.g., "Sale growth" was replaced by "Revenue growth") or in their computational procedure (e.g., "Cost of sales" was changed to "Cost of sales/Turnover").

\subsubsection{Identification of the Benchmark Values}

For each KPI, Table 2 specifies whether a benchmark is required and, in that case, the type of benchmark used. The choice of the benchmark, as well as the subsequent step of the scales' definition were carried out by the authors alone; indeed, the managers of Company A were not involved in order to avoid biases in the evaluation.

Three KPIs (i.e., "Delivery flexibility", "Customization" and "Rate of multiple sourcing") turned out not to require a benchmark for the analysis. For the remaining $23 \mathrm{KPIs}$, either the best competitor (for $16 \mathrm{KPIs}$ ) or an official benchmark (for seven KPIs) was identified.

As far as the best competitor is concerned, Company A is a leader in Italy in the production of milling machines and ranks second worldwide. Its global best competitor is a Swiss company, which, however, does not operate expressly in the segment of milling machines, but in the more general food machinery industry. This consideration, coupled with the fact that the Swiss scenario could be different from the Italian one, led to the conclusion that using this company as the benchmark could lead to a somehow inconsistent evaluation. Therefore, the Italian best competitor (Company B) was taken as the benchmark; such a choice should ensure that the performances of the two companies are comparable. The set of economic data related to Company B was derived from the analysis of the latest available (2015) balance sheet, while the performance against the environmental and social KPIs either were known to the managers of Company A or were collected by means of direct contacts with Company B, in April 2016.

An official benchmark was identified for "Carbon footprint", "Work shift", "Salary", "Employment gender ratio", "Job training", "Full-time workers" and "Work injury".

\subsubsection{Computational Procedure and Scale Definition}

For all end-level KPIs, four-point linguistic scales (from VP to VG) with trapezoidal fuzzy number were chosen for the assessment. A five-point scale (including the A judgement) was used to express the results of the aggregation of KPIs. The representation of the trapezoidal fuzzy numbers (i.e., $a, b, c$ and $d$ in Equation (1)) was obtained starting from the boundaries of the linguistics judgements and following standard scales available in the literature [18]. As far as the computation of the "final score" is concerned, Table 2 shows different situations, i.e.,

- for the three KPIs that do not require a benchmark, the boundaries of the linguistic judgements were set by the authors by interviewing experts in the food machinery industry and by consulting some available references related to the themes of delivery flexibility [80], product customization [81] and multiple sourcing [82] in the ETO environment;

- for the 16 KPIs for which the best competitor is used as the benchmark (e.g., "Sales growth"), the "final score" of Company A against the KPI was computed as the ratio between its performance and that of Company B; with respect to the fuzzy linguistic scale, as a general rule, the performance of Company A was judged as VG if it exceeds the best competitor's performance by at least $20 \%$ 
and VP if it is more than $20 \%$ worse than that of the best competitor; this is the case for a benefit KPI, while the opposite situation holds for a cost KPI (e.g., "Cost of sales");

- for the seven KPIs for which an official benchmark is available, different computational procedures were used depending on the specific KPI.

- For some KPIs, the "final score" of Company A was computed as the ratio between its performance and the official benchmark. This is, for instance, the case for "Salary", for which the official benchmark (i.e., the collective labor agreement for the mechanical industry) suggests approximately $27,000 €$ /year as the standard payment for a worker of the mechanical industry. The average salary Company A applies to its workers was directly compared to this value to get the "final score". The performance of Company A was judged as VG if it exceeds the benchmark by at least $20 \%$ and VP if it is more than $20 \%$ worse than the benchmark. Similar considerations were applied to "Job training", as well as to "Carbon footprint" and "Work injury", although for these latter KPIs, a reversed scale was used (as they are cost attributes);

- For "Work shift", the official benchmark (i.e., again the collective labor agreement for the mechanical industry) suggests 40 hours/week as the standard working time in the mechanical industry. To derive the "final score", we computed the absolute percentage deviation between the number of hours worked by Company A's employees and the benchmark value, i.e., $\left|\frac{\text { Score }_{A}-\text { benchmark }}{\text { benchmark }}\right|$. The rationale for this computation is that the company should be fully aligned with the benchmark to be considered as G or VG, while significant deviations, both positive (excessive working time) and negative (too limited working time) from the target should be considered as P or VP. The scale has been defined to capture this situation;

- For other KPIs, a scale compliant with the guidelines of the official benchmark was defined. This is, for instance, the case of "Employment gender ratio", for which the benchmark is the average percentage of women at work in Italy as computed by the Italian Institute of Statistics (ISTAT) [83]. ISTAT [83] estimates an average of $41 \%$ of women at work, which was used as the benchmark. Following the same general rule adopted for other KPIs, the performance of Company A was judged as VP if it is more than $20 \%$ worse (i.e., $<33 \%$ ) than the benchmark and VG if it exceeds the benchmark by at least $20 \%$ (i.e., $>48 \%$ ). Similar considerations were made for "Full-time workers".

\subsubsection{Hierarchy Structure of KPIs}

The authors built the hierarchy structure of the KPIs in the software tool, starting from the original scheme in Figure 2 and taking into account the KPIs removed or modified. The proposed hierarchy was approved by the managers of Company A and is shown in Figure 12.

\subsubsection{Fuzzy If-Then Rules}

The fuzzy if-then rules chosen assume the same relative importance of each end-level KPI, as well as of the three sustainability perspectives; therefore, they reflect the rules described in Section 3.2. 
Table 2. List of the sustainability KPIs for the case study. ETO, engineer-to-order.

\begin{tabular}{|c|c|c|c|c|c|c|}
\hline & KPI & $\begin{array}{l}\text { Used in the } \\
\text { Case Study? }\end{array}$ & Adaptations/Reason for Removal & $\begin{array}{l}\text { Measurement } \\
\text { Unit }\end{array}$ & Benchmark & Fuzzy Linguistic Scale \\
\hline \multirow{16}{*}{$\begin{array}{c}\text { Economic } \\
\text { perspective }\end{array}$} & Delivery flexibility & Yes & $\begin{array}{l}\text { It was computed as the ratio between the number of deliveries } \\
\text { (of finished products) that meet the delivery date defined by Company A } \\
\text { and the number of deliveries fulfilled by the company. This KPI was } \\
\text { computed for the three main types of order fulfilled by Company A } \\
\text { (i.e., spare part, plant/equipment and machinery), and the average value } \\
\text { was taken as the company's performance. }\end{array}$ & $\%$ & $\begin{array}{c}\text { none } \\
\text { (the higher the better) }\end{array}$ & $\begin{array}{l}\text { VP: }<55 \% \text {; P: } 50-74 \% \text {; } \\
\text { G: } 70-95 \% \text {; VG: 88-100\% }\end{array}$ \\
\hline & Mix flexibility & No & As Company A works on an ETO basis, mix flexibility is meaningless. & - & - & - \\
\hline & Customization & Yes & - & $\%$ & $\begin{array}{l}\text { none } \\
\text { (the higher the better) }\end{array}$ & $\begin{array}{l}\text { VP: }<25 \% ; \text { P: 20-50\%; } \\
\text { G: 45-75\%; VG: >70\% }\end{array}$ \\
\hline & Warehouse turnover rate & Yes & $\begin{array}{l}\text { This KPI was computed taking into account the whole stock available at } \\
\text { Company A, including finished products, semi-finished products } \\
\text { and components. }\end{array}$ & Months $^{-1}$ & best competitor & $\begin{array}{l}\text { VP: }<80 \% \text { P: } 70-100 \% \\
\text { G: } 90-130 \% ; \text { VG: }>120 \%\end{array}$ \\
\hline & Rate of defects & No & $\begin{array}{l}\text { Company A checks all new plants before delivering them to the } \\
\text { customers, and all defects are fixed during this check. Returns of product } \\
\text { because of defects are very likely to be observed. }\end{array}$ & - & - & - \\
\hline & Customer satisfaction & No & See the previous KPI. & - & - & - \\
\hline & Rate of multiple sourcing & Yes & - & $\%$ & $\begin{array}{c}\text { none } \\
\text { (the higher the better) }\end{array}$ & $\begin{array}{l}\text { VP: }<8 \% ; \text { P: 5-16\%; } \\
\text { G: } 14-27 \% ; \text { VG: }>25 \%\end{array}$ \\
\hline & Stock out & No & $\begin{array}{l}\text { Because Company A works on an ETO basis, products are not } \\
\text { manufactured to be kept in stock. Therefore, measuring out-of-stock } \\
\text { situations is meaningless. }\end{array}$ & - & - & - \\
\hline & Sale growth $\rightarrow$ Revenue growth & Yes & $\begin{array}{l}\text { The sale growth does not fully allow capturing the situation of an ETO } \\
\text { company. The company's managers suggested to replace it with the } \\
\text { increase in the revenue from contracts, which is monitored annually by } \\
\text { Company A and describes the amount of orders Company A has received } \\
\text { from its customers in one year. }\end{array}$ & $\%$ & best competitor & $\begin{array}{l}\text { VP: }<80 \% \text {; P: 70-100\%; } \\
\text { G: } 90-130 \% \text {; VG: >120\% }\end{array}$ \\
\hline & Market share & Yes & $\begin{array}{l}\text { As the best competitor (Company B) works in several market sectors, to } \\
\text { compute the KPI, we took into account its market share limited to the } \\
\text { milling industry. }\end{array}$ & $\%$ & best competitor & $\begin{array}{l}\text { VP: }<80 \% ; \text { P: } 70-100 \% ; \\
\text { G: } 90-130 \% ; \text { VG: }>120 \%\end{array}$ \\
\hline & ROI & Yes & - & $\%$ & best competitor & $\begin{array}{l}\text { VP: }<80 \% \text {; P: 70-100\%; } \\
\text { G: } 90-130 \% \text {; VG: }>120 \%\end{array}$ \\
\hline & Turnover & Yes & - & $€$ & best competitor & $\begin{array}{l}\text { VP: }<80 \% \text {; P: 70-100\%; } \\
\text { G: } 90-130 \% ; \text { VG: }>120 \%\end{array}$ \\
\hline & $\begin{array}{l}\text { Cost of sales } \rightarrow \text { Cost of } \\
\text { sales/Turnover }\end{array}$ & Yes & $\begin{array}{l}\text { This KPI was computed as the ratio between the cost of sales and the } \\
\text { turnover (both derived from the company's balance sheet) to allow a } \\
\text { more meaningful comparison with the best competitor. }\end{array}$ & $\%$ & best competitor & $\begin{array}{l}\text { VP: }>120 \% \text {; P: } 90-130 \% \text {; } \\
\text { G: } 70-100 \% \text {; VG: }<80 \%\end{array}$ \\
\hline & $\begin{array}{c}\text { Inventories } \rightarrow \\
\text { Inventories/Turnover }\end{array}$ & Yes & See the previous KPI. & $\%$ & best competitor & $\begin{array}{l}\text { VP: }<80 \% \text {; P: } 70-100 \% ; \\
\text { G: } 90-130 \% \text {; VG: }>120 \%\end{array}$ \\
\hline & $\begin{array}{l}\text { Investments in R\&D } \rightarrow \\
\text { Investments in R\&D/Turnover }\end{array}$ & Yes & See the previous KPI. & $\%$ & best competitor & $\begin{array}{l}\text { VP: }<80 \% \text {; P: 70-100\%; } \\
\text { G: } 90-130 \% \text {; VG: }>120 \%\end{array}$ \\
\hline & Net profit $\rightarrow$ Net profit/Turnover & Yes & See the previous KPI. & $\%$ & best competitor & $\begin{array}{l}\text { VP: }<80 \% ; \text { P: } 70-100 \% ; \\
\text { G: } 90-130 \% ; \text { VG: }>120 \%\end{array}$ \\
\hline
\end{tabular}


Table 2. Cont

\begin{tabular}{|c|c|c|c|c|c|c|}
\hline & KPI & $\begin{array}{l}\text { Used in the } \\
\text { Case Study? }\end{array}$ & Adaptations/Reason for Removal & $\begin{array}{l}\text { Measurement } \\
\text { Unit }\end{array}$ & Benchmark & Fuzzy Linguistic Scale \\
\hline \multirow{11}{*}{$\begin{array}{c}\text { Environmental } \\
\text { perspective }\end{array}$} & Eco-design & Yes & - & $\%$ & best competitor & $\begin{array}{l}\text { VP: }<80 \% \text {; P: } 70-100 \% \text {; } \\
\text { G: } 90-130 \% \text {; VG: }>120 \%\end{array}$ \\
\hline & Carbon footprint & Yes & $\begin{array}{l}\text { We used the average value computed by Company A on three main types } \\
\text { of machines manufactured. Such an average value was compared to some } \\
\text { available environmental product declarations (EPD) of similar products, } \\
\text { as the benchmark. }\end{array}$ & $\mathrm{kg} \mathrm{CO} 2$ eq. & $\begin{array}{l}\text { EPD certification of food } \\
\text { machines }[84,85]\end{array}$ & $\begin{array}{l}\text { VP: }>120 \% ; \text { P: } 90-130 \% \\
\text { G: } 70-100 \% ; \text { VG: }<80 \%\end{array}$ \\
\hline & Energy footprint & No & $\begin{array}{l}\text { At the time of writing, Company A is carrying out a complete LCA } \\
\text { analysis of their main machines, but the related results are still not } \\
\text { available. We have therefore neglected this KPI. }\end{array}$ & - & - & - \\
\hline & Water consumption & No & See the previous KPI. & - & - & - \\
\hline & Air emissions & No & $\begin{array}{l}\text { At the time of writing, Company A has never evaluated its air emissions. } \\
\text { We have therefore neglected this KPI. }\end{array}$ & - & - & - \\
\hline & Use of hazardous materials & No & $\begin{array}{l}\text { This KPI is not particularly relevant to plant manufacturers and is not } \\
\text { expect to vary significantly across plant manufacturing companies. }\end{array}$ & - & - & - \\
\hline & Product recycling rate & No & $\begin{array}{l}\text { Company's products are durable goods, whose lifecycle can reach } 50 \\
\text { years. Therefore, end-of-life management is a marginal problem for } \\
\text { Company A (and more in general, for companies operating as } \\
\text { plant manufacturers). }\end{array}$ & - & - & - \\
\hline & Product non-recycling rate & No & See the previous KPI. & - & - & - \\
\hline & Packaging recycling rate & Yes & - & $\%$ & best competitor & $\begin{array}{l}\text { VP: }<80 \% \text {; P: 70-100\%; } \\
\text { G: } 90-130 \% \text {; VG: }>120 \%\end{array}$ \\
\hline & Packaging non-recycling rate & Yes & - & $\%$ & best competitor & $\begin{array}{l}\text { VP: }<80 \% \text {; P: } 70-100 \% \text {; } \\
\text { G: } 90-130 \% \text {; VG: }>120 \%\end{array}$ \\
\hline & Unitary transport cost & No & $\begin{array}{l}\text { This KPI is not particularly relevant to plant manufacturers, as they are } \\
\text { often forced to make use of container shipments because of the size of the } \\
\text { product shipped. Therefore, the transport cost is not expected to vary } \\
\text { significantly across these companies. }\end{array}$ & - & - & - \\
\hline
\end{tabular}


Table 2. Cont

\begin{tabular}{|c|c|c|c|c|c|c|}
\hline & KPI & $\begin{array}{l}\text { Used in the } \\
\text { Case Study? }\end{array}$ & Adaptations/Reason for Removal & $\begin{array}{c}\text { Measurement } \\
\text { Unit }\end{array}$ & Benchmark & Fuzzy Linguistic Scale \\
\hline \multirow{13}{*}{$\begin{array}{c}\text { Social } \\
\text { perspective }\end{array}$} & Work shift & Yes & - & hours/week & $\begin{array}{l}\text { collective labor agreement for } \\
\text { the mechanical industry [86] }\end{array}$ & $\begin{array}{c}\text { VP: }>7 \% \text {; P: 5-8\%; G: 3-6\%; } \\
\text { VG: }<4 \%\end{array}$ \\
\hline & Salary & Yes & - & $€ /$ year & $\begin{array}{l}\text { collective labor agreement for } \\
\text { the mechanical industry }[86]\end{array}$ & $\begin{array}{l}\text { VP: }<80 \% \text {; P: 70-100\%; } \\
\text { G: } 90-130 \% ; \text { VG: >120\% }\end{array}$ \\
\hline & Employment gender ratio & Yes & $\begin{array}{l}\text { This KPI was computed considering both full-time workers and interim } \\
\text { employees, which could be employed at Company A for a limited time } \\
\text { during peaks of work. }\end{array}$ & $\begin{array}{l}\text { \% of women } \\
\text { at work }\end{array}$ & $\begin{array}{l}\text { average percentage of } \\
\text { women at work in Italy [87] }\end{array}$ & $\begin{array}{l}\text { VP: }<35 \% ; \text { P: } 33-43 \% ; \\
\text { G: } 38-48 \% \text {; VG: }>46 \%\end{array}$ \\
\hline & Job training & Yes & See the previous KPI. & hours/year & $\begin{array}{l}\text { average amount of hours for } \\
\text { job training in Italy [87] }\end{array}$ & $\begin{array}{l}\text { VP: }<80 \% \text {; P: 70-100\%; } \\
\text { G: } 90-130 \% ; \text { VG: >120\% }\end{array}$ \\
\hline & Full-time workers & Yes & - & $\%$ & $\begin{array}{l}\text { average percentage of } \\
\text { full-time workers in Italy [88] }\end{array}$ & $\begin{array}{l}\text { VP: }<50 \% ; \text { P: } 48-70 \% ; \\
\text { G: 68-90\%; VG: >88\% }\end{array}$ \\
\hline & Temporal working continuity & Yes & - & - & best competitor & $\begin{array}{l}\text { VP: }<80 \% \text {; P: 70-100\%; } \\
\text { G: } 90-130 \% ; \text { VG: >120\% }\end{array}$ \\
\hline & Safety training & No & $\begin{array}{l}\text { As in Italy, safety training is mandatory for any worker and is regulated } \\
\text { by specific laws, this KPI scores } 100 \% \text { for any Italian company. }\end{array}$ & - & - & - \\
\hline & Work injury & Yes & - & $\%$ & $\begin{array}{l}\text { standardized accident } \\
\text { rates of Europe [89] }\end{array}$ & $\begin{array}{l}\text { VP: >120\%; P: } 90-130 \% \text {; } \\
\text { G: } 70-100 \% \text {; VG: }<80 \%\end{array}$ \\
\hline & Local suppliers & Yes & $\begin{array}{l}\text { Suppliers were considered as local if they are located in a range of } 50 \mathrm{~km} \\
\text { from the company. }\end{array}$ & $\%$ & best competitor & $\begin{array}{l}\text { VP: }<80 \% \text {; P: 70-100\%; } \\
\text { G: } 90-130 \% \text {; VG: }>120 \%\end{array}$ \\
\hline & Local workers & Yes & $\begin{array}{l}\text { Workers were considered as local if they are located in a range of } 50 \mathrm{~km} \\
\text { from the company. }\end{array}$ & $\%$ & best competitor & $\begin{array}{l}\text { VP: }<80 \% \text {; P: 70-100\%; } \\
\text { G: } 90-130 \% ; \text { VG: >120\% }\end{array}$ \\
\hline & Claims & No & $\begin{array}{l}\text { Company A checks all new plants before delivering them to the } \\
\text { customers, and all defects are fixed during this check. Claims after this } \\
\text { check are very unlikely to occur. }\end{array}$ & - & - & - \\
\hline & $\begin{array}{l}\text { Supplier's screening } \\
\text { for human rights }\end{array}$ & No & $\begin{array}{l}\text { The screening of the suppliers for human rights is currently not } \\
\text { performed by Company A and Company B. Therefore, this KPI was } \\
\text { neglected in the analysis. }\end{array}$ & - & - & - \\
\hline & Sustainable suppliers & Yes & - & $\%$ & best competitor & $\begin{array}{l}\text { VP: }<80 \% \text {; P: 70-100\%; } \\
\text { G: } 90-130 \% ; \text { VG: }>120 \%\end{array}$ \\
\hline
\end{tabular}




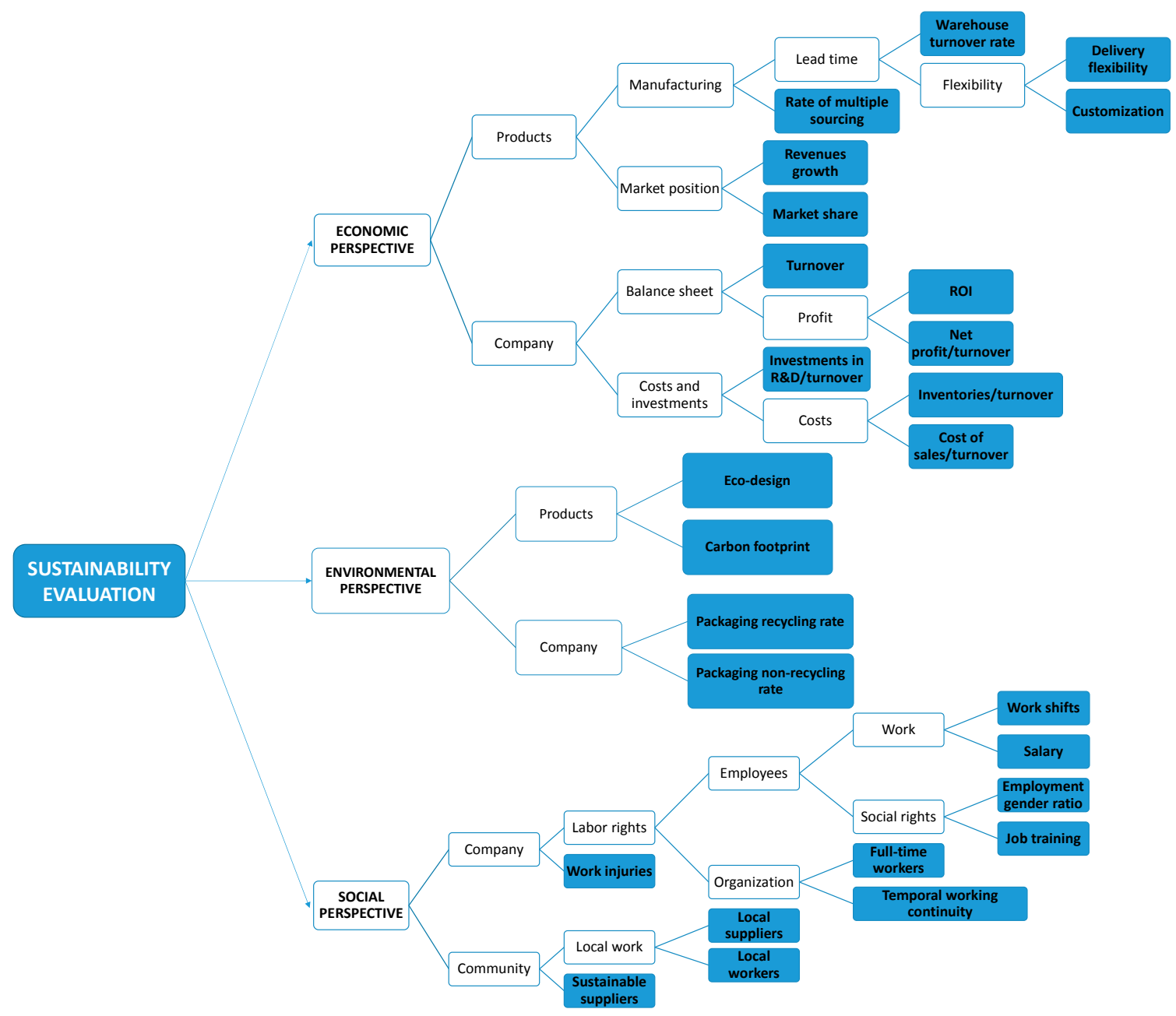

Figure 12. Hierarchy structure of the sustainability evaluation for Company A.

\subsection{Results and Discussion}

As the computational procedure is the same for all sustainability perspectives, in the following, we detail the model application with reference to the economic perspective, for brevity. Table 3 lists the input data collected for the economic KPIs, i.e., the performance of Company A and the benchmark values.

The company's performance and the benchmark values reported in Table 3 were input in the graphical interface of the fuzzy inference tool, which returned the "final scores" listed in the fourth column of the table. These values were subject to fuzzification, according to the scales previously detailed in Table 2, obtaining a membership value for each linguistic judgement. As an example, with the linguistic judgements expressed for "Delivery flexibility" (i.e., VP: <55\%; P: 50-74\%; G: 70-95\%; VG: $88-100 \%$ ) and applying the fuzzy scale proposed by [38], the company's performance was rated as $\mathrm{G}$ with $\mu=0.71$ and VG with $\mu=0.29$. Overall, the fuzzy numbers and linguistic judgements obtained for the economic KPIs and the related membership degree are reported in the last column of Table 3. The fuzzy inference tool was used to aggregate the economic KPIs, according to the scheme in Figure 12. By repeating the inference process iteratively, the fuzzy inference tool returned an economic performance of Company A rated as VG with $\mu=1.00$.

As far as the environmental and social perspectives are concerned, the related input data, i.e., the performance of Company A and the benchmark values, are listed in Tables 4 and 5, respectively. 
Table 3. Input data for Company A: economic perspective.

\begin{tabular}{|c|c|c|c|c|}
\hline KPI & $\begin{array}{l}\text { Company's } \\
\text { Performance }\end{array}$ & Benchmark & Final Score & $\begin{array}{l}\text { Linguistic Judgement } \\
\text { (Membership Degree) }\end{array}$ \\
\hline Delivery flexibility & $90 \%$ & - & $90.00 \%$ & $\mathrm{G}(0.71) ; \mathrm{VG}(0.29)$ \\
\hline Customization & $47 \%$ & - & $47.00 \%$ & $P(0.60) ; G(0.40)$ \\
\hline Warehouse turnover rate & 1.7 & 2.0 & $85.00 \%$ & $\mathrm{P}(1)$ \\
\hline Rate of multiple sourcing & $35 \%$ & - & $35.00 \%$ & VG (1) \\
\hline Revenue growth & $139 \%$ & $17 \%$ & $820.38 \%$ & VG (1) \\
\hline Market share & $23 \%$ & $15 \%$ & $153.33 \%$ & VG (1) \\
\hline ROI & $22.6 \%$ & $21.76 \%$ & $103.86 \%$ & $\mathrm{G}(1)$ \\
\hline Turnover & $x x^{1}$ & $\mathrm{xxx}$ & $293.24 \%$ & VG (1) \\
\hline Cost of sales/Turnover & $94.41 \%$ & $87.22 \%$ & $108.25 \%$ & $P(1)$ \\
\hline Inventories/Turnover & $13.99 \%$ & $15.11 \%$ & $92.61 \%$ & $\mathrm{P}(0.74) ; \mathrm{G}(0.26)$ \\
\hline Investments/Turnover & $0.06 \%$ & $0.05 \%$ & $108.32 \%$ & $\mathrm{G}(1)$ \\
\hline Net profit/Turnover & $4.86 \%$ & $10.64 \%$ & $45.61 \%$ & $\mathrm{VP}(1)$ \\
\hline
\end{tabular}

${ }^{1}$ Because of confidentiality reasons, the turnover of both Companies A and B is omitted. This does not jeopardize the analysis, as the "final score" was correctly computed and used in evaluating the sustainability of Company A.

Table 4. Input data for Company A: environmental perspective.

\begin{tabular}{ccccc}
\hline KPI & $\begin{array}{c}\text { Company's } \\
\text { Performance }\end{array}$ & Benchmark & $\begin{array}{c}\text { Final } \\
\text { Value }\end{array}$ & $\begin{array}{c}\text { Linguistic Judgement } \\
\text { (Membership Degree) }\end{array}$ \\
\hline Eco-design & $33 \%$ & $25 \%$ & $132.00 \%$ & VG $(1)$ \\
Carbon footprint & 131,699 & 54,567 & $241.35 \%$ & VP $(1)$ \\
Packaging recycling rate & $88 \%$ & $90 \%$ & $97.78 \%$ & P $(0.22) ; G(0.78)$ \\
Packaging non-recycling rate & $5 \%$ & $3.5 \%$ & $142.86 \%$ & VG $(1)$ \\
\hline
\end{tabular}

Table 5. Input data for Company A: social perspective.

\begin{tabular}{ccccc}
\hline KPI & $\begin{array}{c}\text { Company's } \\
\text { Performance }\end{array}$ & Benchmark & $\begin{array}{c}\text { Final } \\
\text { Value }\end{array}$ & $\begin{array}{c}\text { Linguistic Judgement } \\
\text { (Membership Degree) }\end{array}$ \\
\hline Work shift & 42.12 & 40 & $5.30 \%$ & $\mathrm{P}(0.30) ; \mathrm{G}(0.70)$ \\
Salary & 26,000 & 27,000 & $96.30 \%$ & $\mathrm{P}(0.37) ; \mathrm{G}(0.63)$ \\
Employment gender ratio & $39 \%$ & $41 \%$ & $95.12 \%$ & VG $(1)$ \\
Job training & $92 \%$ & $93 \%$ & $98.92 \%$ & VG $(1)$ \\
Full-time workers & $87 \%$ & $98 \%$ & $88.78 \%$ & $\mathrm{G}(0.61) ; \mathrm{VG}(0.39)$ \\
Temporal working continuity & 1.18 & 1.67 & $70.91 \%$ & $\mathrm{VP}(0.91) ; \mathrm{P}(0.09)$ \\
Work injury & $1.54 \%$ & $1.80 \%$ & $85.47 \%$ & $\mathrm{G}(1)$ \\
Local suppliers & $53 \%$ & $76 \%$ & $69.74 \%$ & $\mathrm{VP}(1)$ \\
Local workers & $71 \%$ & $92 \%$ & $77.17 \%$ & $\mathrm{VP}(0.28) ; \mathrm{P}(0.72)$ \\
Sustainable suppliers & $74 \%$ & $45 \%$ & $164.44 \%$ & $\mathrm{VG}(1)$ \\
\hline
\end{tabular}

By applying the same procedure described above, the fuzzy inference tool rated the environmental perspective of Company A as $\mathrm{G}$ with $\mu=1.00$; the same evaluation was obtained for the social perspective.

The combination of these three performance judgements and the subsequent defuzzification (according to Equation (2)) returned an overall sustainability evaluation of 0.750. It is appropriate to normalize this value to get a more meaningful evaluation of the company's sustainability; Equation (3) was used to this end, using $\min =0.075$ and $\max =0.90$, which corresponds to the results returned by the fuzzy inference tool if the company's performances all score the lowest or highest value of the linguistic scale. The normalized performance scores 0.9090 on a [0-1] scale.

\section{Conclusions}

This paper has proposed a quantitative tool for the assessment of the company's sustainability, according to its key perspectives (i.e., economic, environmental and social). The proposed framework makes use of fuzzy logic, and in particular, it exploits a fuzzy inference tool to gather the judgements 
and scores against the three perspectives into an aggregated index. The fuzzy inference tool was embodied in an ad hoc software tool, developed in Microsoft Excel ${ }^{\mathrm{TM}}$, which enables the adoption of the framework by a DM (e.g., a supply chain manager) for the evaluation of the company's sustainability.

From a theoretical point of view, this study contributes to the literature in several ways. First, although the use of fuzzy logic for sustainability assessment has been proposed in some works [38-40], most of these studies carried out the evaluation of sustainability in macro-systems, while the exhaustive evaluation of sustainability of companies or supply chains is more limited in the literature. Only two examples (i.e., [54,55]) have addressed this point. Second, in developing the fuzzy inference tool, we have also solved some issues related to the definition of scales and the benchmark for the evaluation of the company's performance against each sustainability index. It is important to note that the model includes a unit of measurement also for each social KPI, which was not immediate to identify, as several authors have pointed out the lack of specific and quantitative indexes for social sustainability [5]. For some KPIs, official benchmarks have also been provided. This is an important point, as well, because in the context of sustainability, scores often need to be compared to a reference value, to provide a meaningful evaluation and assess how a company is distant from, or aligned to, a target [17,34-36]. Third, the model allows deriving an overall sustainability index, by aggregating the scores against the different KPIs into a composite index. This meets the increasing need for synthetic indicators for sustainability assessment [32]. The development of a Microsoft Excel ${ }^{\mathrm{TM}}$ software tool, where the hierarchical fuzzy inference model has been embodied, is a further interesting contribution to the literature, as it makes the application of the framework very easy and enables its effective use by DMs. In addition, the software tool has been designed to be flexible enough to allow KPIs to be included, removed or adapted, as a function of the targeted context. The tool is also flexible from a technical point of view, as it allows, for instance, shifting from trapezoidal fuzzy numbers (used in this study) to triangular ones, according to the DM's request. The linguistics scales and the relative importance of the three sustainability perspectives can also be modified easily.

From a practical perspective, the case study carried out allows deriving some important considerations. As a first point, the application confirms that a crucial point in sustainability assessment is the identification of the key aspects of sustainability and of suitable and meaningful metrics for each KPI [32]. Indeed, to apply the model to the chosen company, we preliminary needed to review the sustainability KPIs proposed in the literature to "adapt" them to the specific context analyzed, as well as to identify a meaningful unit of measurement and benchmark for each KPI. At the same time, this means that, although the approach described in the paper is general in nature, customizations might be required to tune the model and adapt it to the company examined, which could be onerous in terms of time and data required. As a further point, the results of the application show that, overall, the sustainability level of the company examined is good (0.909 on a $0-1$ scale), indicating that Company A is sensitive to sustainability issues. At the same time, the performance achieved by the company against the economic, environmental and social perspectives of sustainability differ. The economic perspective, in particular, got the highest score (VG), which confirms the fact that the economic pillar of sustainability is typically addressed by enterprises [7], while the remaining perspectives achieved lower scores $(G)$. These outcomes can be helpful to Company A when prioritizing interventions aimed at enhancing its sustainability level. To this end, the company should begin with improving its performance against the environmental or social KPIs, focusing on the KPIs that were rated as VP or P. As an example, let us suppose that Company A would like to intervene on the social sustainability and try to improve it. One of the social KPIs that got the lowest score is "Local suppliers", for which the company's score is $53 \%$; this value was rated as VP after comparison with the benchmark. If the company were able, for instance, to increase its current score to $60 \%$ (which would be rated as VP with $\mu=0.358$ and $\mathrm{P}$ with $\mu=0.642$ ), its performance against the social perspective of sustainability would become $\mathrm{G}$ with $\mu=0.982$ and VG with $\mu=0.018$. Overall, this would lead to an improved sustainability level of 0.752 . 
Among the technical limitations of this work, we have mentioned that applying our model to a specific context might require preliminary customizations and adaptations, as well as the collection of several input data (e.g., the company's performance and benchmark values). This preliminary step is probably inevitable; nonetheless, future research could try to find suitable methods to make the data collection less onerous. The identification of further official benchmarks (if/when available) could somehow help in this regard, as these benchmarks can be used as general reference regardless of the company examined, thus avoiding the need for collecting specific input data. Again from a technical perspective, we have stated that the results of the application could provide interesting indications to the company examined to prioritize interventions aimed at enhancing its current sustainability level. However, one might question that the urgent interventions could fall outside the company's control. For instance, a company has little control of a KPI such as the "Carbon footprint" of its products, as $\mathrm{CO}_{2}$ emissions depend on the production process, raw material used, energy consumption and other factors that can hardly be modified as the company wishes. The current version of the model does not take into account this issue; nonetheless, trying to embody these considerations into the framework proposed could be an interesting challenge. Finally, future research could address the application of the proposed model to different contexts, to confirm its ease of adoption and usefulness.

Acknowledgments: This research was supported by the research Grant No. D92115000210008 (project code RBSI14L97M), called "ESCALATE-Economic and Environmental Sustainability of Supply Chain and Logistics with Advanced Technologies", funded by the Italian Ministry of University and Research under the SIR (Scientific Independence of young Researchers) 2014 program (decree of 23 January 2014, No. 197) and awarded to the first author.

Author Contributions: Eleonora Bottani acted as the coordinator of this study and was in charge of the general design of the research activities, assembly and review of the related material. Maria Carmen Gentilotti and Marta Rinaldi developed the fuzzy logic-based tool and carried out the application example. The paper was written together by all of the authors.

Conflicts of Interest: The authors declare no conflict of interest. The founding sponsors had no role in the design of the study; in the collection, analyses or interpretation of data; in the writing of the manuscript; nor in the decision to publish the results.

\section{References}

1. Hutchins, M.; Sutherland, J. An exploration of measures of social sustainability and their application to supply chain decisions. J. Clean. Prod. 2008, 16, 1688-1698. [CrossRef]

2. World Commission on Environment and Development. Our Common Future; Oxford University Press: New York, NY, USA, 1987.

3. Harris, J.; Kennedy, S. Carrying capacity in agriculture: Global and regional issues. Ecol. Econ. 1999, 29, 443-461. [CrossRef]

4. Goldman, T.; Gorham, R. Sustainable urban transport: Four innovative directions. Technol. Soc. 2006, 28, 261-273. [CrossRef]

5. Colla, V.; Branca, T.; Vannucci, M.; Fornai, B.; Amato, A. Quantitative sustainability assessment through key performance indicators in ULCOS project. In Proceedings of the 2nd International Seminar on Society \& Materials (SAM2), Nantes, France, 24-25 April 2008.

6. Dyllick, T.; Hockerts, K. Beyond the business case for corporate sustainability. Bus. Strategy Environ. 2002, 11, 130-141. [CrossRef]

7. Seuring, S.; Müller, M. From a literature review to a conceptual framework for sustainable supply chain management. J. Clean. Prod. 2008, 16, 1699-1710. [CrossRef]

8. Seuring, S.; Gold, S. Sustainability management beyond corporate boundaries: From stakeholders to performance. J. Clean. Prod. 2013, 56, 1-6. [CrossRef]

9. Kates, R.; Clark, W.; Corell, R.; Hall, M.; Jaeger, C.; Lowe, I.; McCarthy, J.; Schellnhuber, H.; Bolin, B.; Dickson, N.; et al. Sustainability science. Science 2001, 292, 641-642. [CrossRef] [PubMed]

10. Searcy, C. Measuring enterprise sustainability. Bus. Strategy Environ. 2016, 25, 120-133. [CrossRef] 
11. Bossel, H. Indicators for Sustainable Development: Theory, Method, Applications; Balaton Group (International Institute for Sustainable Development): Winnipeg, MB, Canada, 1999; Available online: http:/ / publ.ext.zalf. de/web/lsa_ergebnisse_agstruk_indikatoren/pdfs\%5Cbalatonreport.pdf (accessed on 28 January 2017).

12. Singh, R.; Murty, H.; Gupta, S.; Dikshit, A. An overview of sustainability assessment methodologies. Ecol. Indic. 2009, 9, 189-212. [CrossRef]

13. Hervani, A.; Helms, M.; Sarkis, J. Performance measurement for green supply chain management. Benchmarking 2005, 12, 330-353. [CrossRef]

14. Lancker, E.; Nijkamp, P. A policy scenario analysis of sustainable agricultural development options: A case study for Nepal. Impact Assess. Proj. Apprais. 2000, 18, 111-124. [CrossRef]

15. Sadler, B. A framework for environmental sustainability assessment and assurance. In Handbook of Environmental Impact Assessment; Blackwell: Oxford, UK, 1999; pp. 12-32.

16. Pope, J.; Annandale, D.; Morrison-Saunders, A. Conceptualising sustainability assessment. Environ. Impact Assess. Rev. 2004, 24, 595-616. [CrossRef]

17. Ugwu, O.O.; Haupt, T.C. Key performance indicators and assessment methods for infrastructure sustainability—a South African construction industry perspective. Build. Environ. 2007, 42, 665-680. [CrossRef]

18. Phillis, Y.; Andriantiatsaholiniaina, L. Sustainability: An ill-defined concept and its assessment using fuzzy logic. Ecol. Econ. 2001, 37, 435-456. [CrossRef]

19. Andriantiatsaholiniaina, L.; Kouikoglou, V.; Phillis, Y. Evaluating strategies for sustainable development: Fuzzy logic reasoning and sensitivity analysis. Ecol. Econ. 2004, 48, 149-172. [CrossRef]

20. Sabaghi, M.; Mascle, C.; Baptiste, P.; Rostamzadeh, R. Sustainability assessment using fuzzy-inference technique (SAFT): A methodology toward green products. Expert Syst. Appl. 2016, 56, 69-79. [CrossRef]

21. Tsoulfas, G.; Pappis, C. Environmental principles applicable to supply chains design and operation. J. Clean. Prod. 2006, 14, 1593-1602. [CrossRef]

22. Carter, C.; Rogers, D. A framework of sustainable supply chain management: Moving toward new theory. Int. J. Phys. Distrib. Logist. Manag. 2008, 38, 360-387. [CrossRef]

23. Wu, H.; Dunn, S. Environmentally responsible logistics systems. Int. J. Phys. Distrib. Logist. Manag. 1995, 25, 20-39. [CrossRef]

24. Murphy, P.; Poist, R.; Braunschwieg, C. Green logistics: Comparative views of environmental progressives, moderates, and conservatives. J. Bus. Logist. 1996, 17, 191-211.

25. Sheu, J.-B.; Chou, Y.-H.; Hu, C.-C. An integrated logistics operational model for green-supply chain management. Transp. Res. Part E 2005, 41, 287-313. [CrossRef]

26. Kim, S.; Yoon, S.-G.C.S.; Park, S. Economic and Environmental Optimization of a Multi-Site Utility Network for an Industrial Complex. J. Environ. Manag. 2010, 91, 690-705. [CrossRef] [PubMed]

27. Min, H.; Galle, W. Green purchasing strategies: Trends and implications. Int. J. Purch. Mater. Manag. 1997, 33, 10-17. [CrossRef]

28. Eskandarpour, M.; Dejax, P.; Miemczyk, J.; Péton, O. Sustainable supply chain network design: An optimization-oriented review. Omega 2015, 54, 11-32. [CrossRef]

29. Pan, S.; Ballot, E.; Fontane, F. The reduction of greenhouse gas emissions from freight transport by pooling. Int. J. Prod. Econ. 2013, 143, 86-94. [CrossRef]

30. Li, H.-C. Optimal delivery strategies considering carbon emissions, time-dependent demands and demand-supply interactions. Eur. J. Oper. Res. 2015, 241, 739-748. [CrossRef]

31. Guide, V.; Jayaraman, V.; Srivastava, R.; Benton, W. Supply chain management for recoverable manufacturing systems. Interfaces 2000, 30, 125-142. [CrossRef]

32. Srivastava, S. Green supply-chain management: A state-of the-art literature review. Int. J. Manag. Rev. 2007, 9, 53-80. [CrossRef]

33. Fleischmann, M.; Bloemhof-Ruwaard, J.; Dekker, R.; van der Laan, E.; van Nunen, J.; van Wassenhove, J. Quantitative models for reverse logistics: A review. Eur. J. Oper. Res. 1997, 103, 1-17. [CrossRef]

34. Seuring, S. Integrated chain management and supply chain management comparative analysis and illustrative cases. J. Clean. Prod. 2004, 12, 1059-1071. [CrossRef]

35. Kleindorfer, P.; Singhal, K.; van Wassenhove, L. Sustainable operations management. Prod. Oper. Manag. 2005, 14, 482-492. [CrossRef]

36. Sarkis, J.; Helms, M.; Hervani, A. Reverse Logistics and Social Sustainability. Corp. Soc. Responsib. Environ. Manag. 2010, 17, 337-354. [CrossRef] 
37. Sarkis, J.; Dhavale, D. Supplier selection for sustainable operations: A triple-bottom-line approach using a Bayesian framework. Int. J. Prod. Econ. 2015, 166, 177-191. [CrossRef]

38. Igarashi, M.; de Boer, L.; Fet, A.M. What is required for greener supplier selection? A literature review. J. Purch. Supply Manag. 2013, 19, 247-263. [CrossRef]

39. Lin, C.; Madu, C.; Kuei, C.-H.; Tsai, H.-L.; Wang, K.-N. Developing an assessment framework for managing sustainability programs: A Analytic Network Process approach. Expert Syst. Appl. 2015, 42, 2488-2501. [CrossRef]

40. Böhringer, C.; Jochem, P. Measuring the immeasurable-A survey of sustainability indexes. Ecol. Econ. 2007, 63, 1-8. [CrossRef]

41. Ness, B.; Urbel-Piirsalu, E.; Anderberg, S.; Olsson, L. Categorising tools for sustainability assessment. Ecol. Econ. 2007, 60, 498-508. [CrossRef]

42. Todorov, V.; Marinova, D. Modelling sustainability. Math. Comput. Simul. 2011, 81, 1397-1408. [CrossRef]

43. Boulanger, P.-M.; Bréchet, T. Models for policy-making in sustainable development: The state of the art and perspectives for research. Ecol. Econ. 2005, 55, 337-350. [CrossRef]

44. Faucheux, S.; Pearce, D.; Proops, J. Models of Sustainable Development; Edward Elgar Publishing: Brookfield, VT, USA, 1996.

45. O’Doherty, J.; Mayor, K.; Tol, R. Irish Sustainable Development Model (ISUS): Literature Review, Data Availability and Model Design. 2007. Available online: http://www.esri.ie/UserFiles/publications/ 20070403121154/WP186.pdf (accessed on 28 March 2010).

46. Hassini, E.; Surti, C.; Searcy, C. A literature review and a case study of sustainable supply chains with a focus on metrics. Int. J. Prod. Econ. 2012, 140, 69-82. [CrossRef]

47. Ahi, P.; Searcy, C. An analysis of metrics used to measure performance in green and sustainable supply chains. J. Clean. Prod. 2015, 86, 360-377. [CrossRef]

48. Wilson, J. The triple bottom line-Undertaking an economic, social, and environmental retail sustainability strategy. Int. J. Retail Distrib. Manag. 2015, 43, 432-447. [CrossRef]

49. Hassini, A.T. A data envelopment analysis approach to evaluate sustainability in supply chain networks. J. Clean. Prod. 2015, 105, 74-85.

50. Mota, B.; Gomes, M.; Carvalho, A.; Barbosa-Povoa, A. Towards supply chain sustainability: Economic, environmental and social design and planning. J. Clean. Prod. 2015, 105, 14-27. [CrossRef]

51. Chen, Z.; Andresen, S. A Multiobjective Optimization Model of Production-Sourcing for Sustainable Supply Chain with Consideration of Social, Environmental, and Economic Factors. Math. Probl. Eng. 2014, 2014, 616107. [CrossRef]

52. Ahi, P.; Searcy, C. Assessing sustainability in the supply chain: A triple bottom line approach. Appl. Math. Model. 2015, 39, 2882-2896. [CrossRef]

53. Kouikoglou, V.; Phillis, Y. Application of a fuzzy hierarchical model to the assessment of corporate social and social sustainability. Corp. Soc. Responsib. Environ. Manag. 2011, 18, 209-219. [CrossRef]

54. Phillis, Y.; Davis, B. Assessment of Corporate Sustainability via Fuzzy Logic. J. Intell. Robot. Syst. 2009, 55, 3-20. [CrossRef]

55. Moldan, B.; Janousková, S.; Hák, T. How to understand and measure environmental sustainability: Indicators and targets. Ecol. Indic. 2012, 17, 4-13. [CrossRef]

56. Sarkis, J. A strategic decision framework for green supply chain management. J. Clean. Prod. 2003, 11, 397-409. [CrossRef]

57. Vanpoucke, E.; Vereecke, A.; Wetzels, M. Developing supplier integration capabilities for sustainable competitive advantage: A dynamic capabilities approach. J. Oper. Manag. 2014, 32, 446-461. [CrossRef]

58. Shafiee, M.; Lotfi, F.H.; Saleh, H. Supply chain performance evaluation with data envelopment analysis and balanced scorecard approach. Appl. Math. Model. 2014, 38, 5092-5112. [CrossRef]

59. Vermeulen, W.; Metselaar, J. Improving sustainability in global supply chains with private certification standards: Testing an approach for assessing their performance and impact potential. Int. J. Bus. Glob. 2015, 14, 226-250. [CrossRef]

60. Mefford, R. The Economic Value of a Sustainable Supply Chain. Bus. Soc. Rev. 2011, 116, 109-143. [CrossRef]

61. Searcy, C.; Karapetrovic, S.; McCartney, D. Designing corporate sustainable development indicators: Reflections on a process. Environ. Qual. Manag. 2009, 19, 31-42. [CrossRef] 
62. Chen, R.-Y. An innovative decision-support approach for design consideration EOL in feedback-based sustainable supply chain. Int. J. Adv. Oper. Manag. 2015, 7, 114-135. [CrossRef]

63. Kucukvar, M.; Cansev, B.; Egilmez, G.; Onat, N.; Samadi, H. Energy-climate-manufacturing nexus: New insights from the regional and global supply chains of manufacturing industries. Appl. Energy 2016, 184, 889-904. [CrossRef]

64. Zhu, Q.; Sarkis, J. Relationships between operational practices and performance among early adopters of green supply chain management practices in Chinese manufacturing enterprises. J. Oper. Manag. 2004, 22, 265-289. [CrossRef]

65. Kuik, S.; Kaihara, T.; Fujii, N.; Kokuryo, D. The Optimal Product Disposition Decision for Product Returns towards Sustainable Manufacturing. Eng. Lett. 2016, 24, 301-306.

66. Haghighi, S.M.; Torabi, S.; Ghasemi, R. An integrated approach for performance evaluation in sustainable supply chain networks (with a case study). J. Clean. Prod. 2016, 137, 579-597. [CrossRef]

67. Yakovieva, N.; Sarkis, J.; Sloan, T. Sustainable Benchmarking of Food Supply Chains. 2009. Available online: https:/ / www2.clarku.edu/departments/marsh/news/WP2009-02.pdf (accessed on 2 January 2017).

68. Verdecho, M.; Alfaro-Saiz, J.; Rodriguez-Rodriguez, R. A performance measurement framework for monitoring supply chain sustainability. In Annals of Industrial Engineering; Springer: London, UK, 2012; pp. 331-338.

69. Tajbakhsh, A.; Hassini, E. Performance measurement of sustainable supply chains: A review and research questions. Int. J. Prod. Perform. Manag. 2015, 64, 744-783. [CrossRef]

70. Vallance, S.; Perkins, H.; Dixon, J. What is social sustainability? A clarification of concepts. Geoforum 2011, 42, 342-348. [CrossRef]

71. Vachon, S.; Klassen, R. Extending green practices across the supply chain: The impact of upstream and downstream integration. Int. J. Oper. Prod. Manag. 2006, 26, 795-821. [CrossRef]

72. Molamohamadi, Z.; N, I.; Leman, Z.; Zulkifli, N. Supplier Selection in a Sustainable Supply Chain. J. Adv. Manag. Sci. 2013, 1, 278-281. [CrossRef]

73. Amindoust, A.; Ahmed, S.; Saghafinia, A.; Bahreininejad, A. Sustainable supplier selection: A ranking model based on fuzzy inference system. Appl. Soft Comput. 2012, 12, 1668-1677. [CrossRef]

74. Sousa, G.; Bose, B. Fuzzy Set Theory Based Control of a Phase-Controlled Converter DC Machine Drive. IEEE Trans. Ind. Appl. 1994, 30, 34-44. [CrossRef]

75. Chen, T.-Y.; Ku, T.-C. Importance-Assessing Method with Fuzzy Number-Valued Fuzzy Measures and Discussions on TFNs and TrFNs. Int. J. Fuzzy Syst. 2008, 10, 92-103.

76. Mandami, E.; Assilian, S. An experiment in linguistic synthesis with a fuzzy logic controller. Int. J. Man Mach. Stud. 1975, 7, 1-13. [CrossRef]

77. Zadeh, L. The concept of a linguistic variable and its application to approximate reasoning. Inf. Sci. 1975, 8, 199-249. [CrossRef]

78. Kouikoglou, V.; Phillis, Y. On the monotonicity of hierarchical sum-product fuzzy systems. Fuzzy Sets Syst. 2009, 160, 3530-3538. [CrossRef]

79. Van Leekwijck, W.; Kerre, E. Defuzzification: Criteria and classification. Fuzzy Sets Syst. 1999, 108, $159-178$. [CrossRef]

80. Gosling, J. Flexibility Strategies for Engineer-to-Order Construction Supply Chains. 2013. Available online: https:/ / orca.cf.ac.uk/54426/1/U584527.pdf (accessed on 2 January 2017).

81. Kristianto, Y.; Helo, P.; Jiao, R. Mass customization design of engineer-to-order products using Benders' decomposition and bi-level stochastic programming. J. Intell. Manuf. 2013, 24, 961-975. [CrossRef]

82. Hicks, C.; McGovern, T.; Earl, C. A typology of UK Engineer-to-Order companies. Int. J. Logist. Res. Appl. 2011, 4, 43-56. [CrossRef]

83. Istat, Il Mercato del Lavoro Negli anni Della Crisi-Dinamiche \& Divari. 2014. Available online: http: / / www.istat.it/it/files/2014/05/cap3.pdf (accessed on 14 October 2016).

84. Fraunhofer Institute for Reliability and Microintegration, Energy-Using Product Group Analysis-Lot 5: Machine Tools and Related Machinery. 2012. Available online: http://www.eup-network.de/fileadmin/ user_upload/Produktgruppen/Lots/Final_Documents/EuP_Lot5_Task3_March2012.pdf (accessed on 31 January 2017). 
85. Fraunhofer Institute for Reliability and Microintegration, Energy-Using Product Group Analysis-Lot 5: Machine Tools and Related Machinery. 2011. Available online: https://www.ebpg.bam.de/de/ebpg medien/entr5/405_studyd_11_02_part3.pdf (accessed on 31 January 2017).

86. Associazioni Sindacali, Contratto Collettivo Nazionale di Lavoro (CCNL) Settore Metalmeccanico per le Lavoratrici \& i LAVORATORI addetti All'industria Metalmeccanica Privata \& alla Installazione di Impianti. 2016. Available online: http:/ / www.contrattometalmeccanici.it (accessed on 9 February 2017). (In Italian)

87. CSR Manager Network Italia \& Istat, Oltre il Dato Finanziario: Imprese \& Benessere Collettivo. 2013. Available online: http://download.terna.it/terna/0000/0064/05.pdf (accessed on 9 February 2017). (In Italian)

88. Istat, “Nero a Metà": Contratti Part-Time \& Posizioni Full-Time fra i Dipendenti delle Imprese Italiane. 2014. Available online: http:/ / www.istat.it/it/files/2014/09/IWP-n.-3-2014.pdf (accessed on 14 October 2016).

89. Health and Safety Executive, European Comparison. 2016. Available online: http://www.hse.gov.uk/ statistics/european/european-comparisons.pdf?pdf=european-comparisons (accessed on 31 January 2017).

(C) 2017 by the authors. Licensee MDPI, Basel, Switzerland. This article is an open access article distributed under the terms and conditions of the Creative Commons Attribution (CC BY) license (http:/ / creativecommons.org/licenses/by/4.0/). 